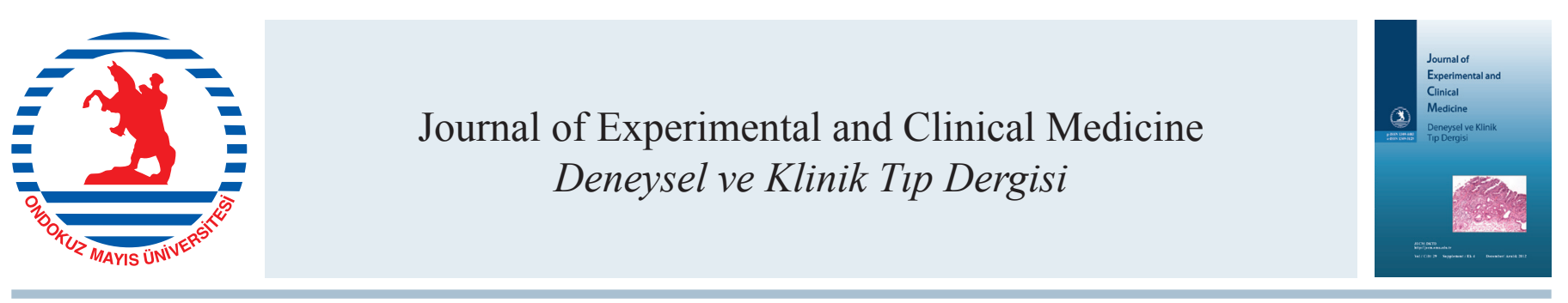

Derleme / Review

doi: $10.5835 /$ jecm.omu.29.s4.005

\title{
Özofagus kanserleri patolojisi
}

\section{Pathology of esophageal carcinomas}

\author{
Duygu Kankaya*, Işınsu Kuzu
}

Ankara Üniversitesi, Tıp Fakültesi, Patoloji Anabilim Dall, Ankara, Türkiye

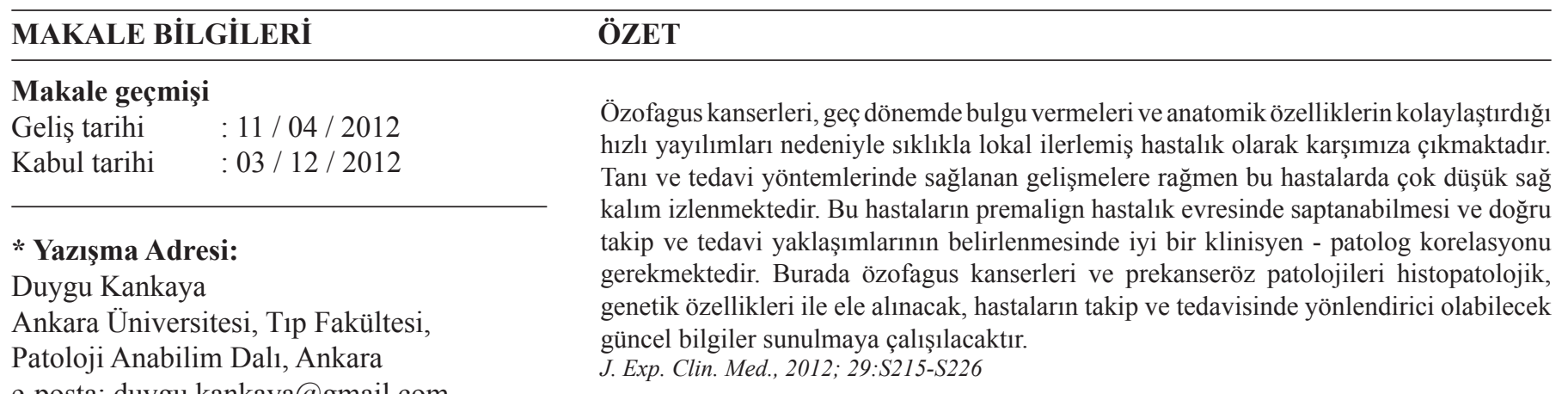

e-posta: duygu.kankaya@gmail.com

\section{Anahtar Kelimeler: \\ Barrett özofagusu \\ Adenokarsinom \\ Yassı hücreli karsinom \\ Özofagus \\ Intraepitelyal neoplazi \\ Öncü lezyon}

\section{Keywords:}

Barrett esophagus

Adenocarcinoma

Squamous cell carcinoma

Esophagus

Intraepithelial neoplasia

Precursor lesion

\begin{abstract}
Esophageal carcinomas can usually be detected in locally advanced stages, due to asymptomatic course and the anatomic properties of esophagus which facilitate rapid spread. Despite improvements on the diagnostic and therapeutic techniques, these patients show very poor survival rates. Detection of these patiens on the premalignant disease stage and determining the appropriate follow-up and therapy approaches require good correlation of the pathologist and the clinician. Here, esophageal carcinomas and their premalignant diseases will be reviewed with histopathological and genetical properties and current information required for follow up and treatment procedures are going to be presented.

J. Exp. Clin. Med., 2012; 29: S215-S226
\end{abstract}

\section{Giriş}

Dünyada kanser tipleri arasında \% 4,2 görülme oranıyla sekizinci sırada olan özofagus kanserleri, ölüm sıklığ1 açısından altıncı sırada yer almaktadır (Parkin ve ark., 2005). Türkiye'de ise tüm kanserlerin \% 2'sini oluşturmakta ve en sık Doğu Anadolu bölgesinde görülmektedir (Koruk ve ark., 2000). Özofagus kanserleri Dünya Sağlık Örgütü 2010 sınıflaması Tablo 1'de belirtilmiştir (Bosman ve ark., 2010) (Tablo 1).

Bunlar arasında sıklık açısından yassı hücreli karsinomalar (YHK) ilk sirada, adenokarsinomalar ise ikinci sirada gelir. $\mathrm{Bu}$ iki tümör tipi özofagus kanserlerinin büyük kısmını oluşturur ve bunlar arasında belirgin epidemiyolojik ve etiyolojik farklılıklar bulunmaktadır. YHK'lar Doğu ülkeleri ve gelişmekte olan ülkelerde daha yoğun olarak izlenirken, geçmiş yıllarda çok daha nadir görülen adenokarsinomalar, her yıl \% 5-10 oranında izlenen görülme sıklığ 1 artışıyla özellikle endüstrileşmiş batı ülkelerinde yoğunlaşmaktadır (Lagergren, 2005; Curado ve ark., 2007). Ortalama 65 yaş civarında görülen bu tümörler adenokarsinomalarda belirgin olarak ortaya çıkan erkek baskınlığı gösterir (Blot ve ark., 2006). Özofagusun genişleme özelliği nedeniyle tümörler lümeni belirgin olarak daraltıp, ileri boyutlara ulaşmasına kadar klinik bulgu vermez ve hastalar sıklıkla ilerlemiş hastalık evresinde disfaji, kilo kaybı, regürjitasyon, retrosternal veya epigastrik ağrı gibi semptomlarla başvurur (Enzinger ve Mayer, 2003). 


\begin{tabular}{l}
$\begin{array}{l}\text { Tablo 1. Özofagus tümörlerinde WHO klasifikasyonu (Bosman } \\
\text { ve ark., 2010) }\end{array}$ \\
Epitelyal tümörler \\
\hline Premalign lezyonlar \\
\hline Yassı hücreli karsinoma premalign lezyonları \\
İntraepitelyal Neoplazi (Displazi), Düşük dereceli \\
İntraepitelyal Neoplazi (Displazi), Yüksek dereceli \\
Adenokarsinoma premalign lezyonları \\
Displazi (İntraepitelyal Neoplazi), Düşük dereceli \\
Displazi (İntraepitelyal Neoplazi), Yüksek dereceli \\
Karsinoma \\
\hline Yassı hücreli karsinoma \\
Varyantları: Verrüköz karsinoma \\
$\quad$ Bazaloid karsinoma \\
$\quad$ Spindl hücreli karsinoma \\
Adenokarsinoma \\
Adenoskuamoz karsinoma \\
Mukoepidermoid karsinoma \\
Adenoidkistik karsinoma \\
Andiferansiye karsinoma \\
Nöroendokrin neoplaziler \\
\hline Nöroendokrin tümör (NET) \\
$\quad$ NET G1 (Karsinoid) \\
$\quad$ NET G2 \\
Nöroendö̈k hücreli NEC \\
Mikst adenonöroendokrin karsinoma \\
\hline
\end{tabular}

\section{Yassı hücreli karsinoma}

Özofagusun en sık görülen malign epitelyal tümörleridir. Etiyolojisinde rol oynayan faktörler Tablo 2'de belirtilmiştir (Tablo 2).

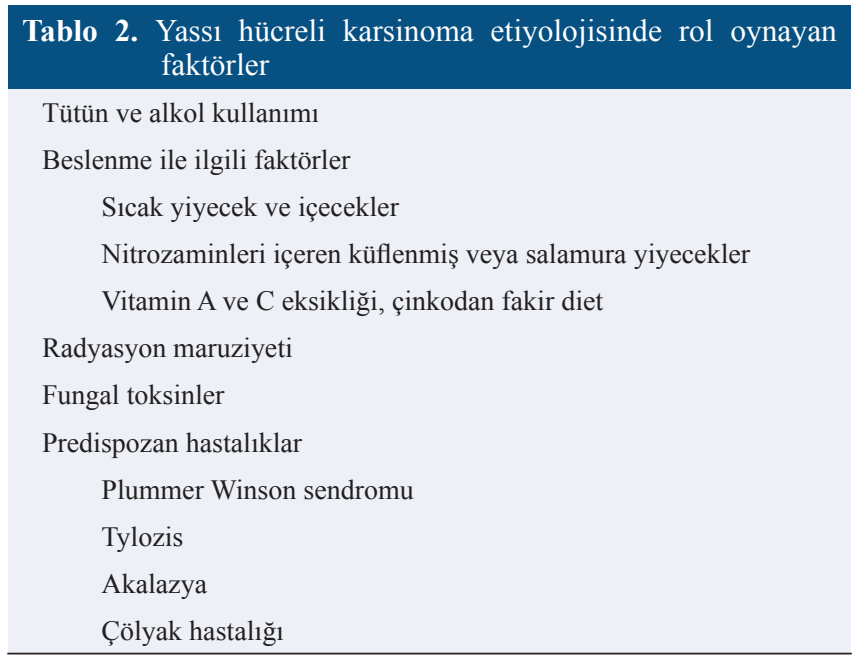

Özellikle Batı ülkelerinde görülen YHK'nın \% 90’’nda tütün ve alkol kullanımı önemli rol oynamaktadır. Özofagus kanseri etiyolojisinde Human papilloma virus enfeksiyonunun rol oynadığını öne süren yayınlar da bulunmaktadır (Farhadi ve ark., 2005).

\section{Makroskopi}

YHK, en s1k özofagus orta 1/3 (\% 50-60), daha az olarak da alt (\% 30) ve üst 1/3'de (\% 10-20) görülür (Hamilton ve Aaltonen, 2000). Çok odaklı gelişim \% 7-28 olguda ve sıklıkla yüzeyel tümörlerde izlenir (Kanamoto ve ark., 2000).

Makroskopik görünüm tümörün invazyon derinliğine göre değişir ve “Japon Özofagus Kanser Topluluğu”nun sınıflamasına göre temel olarak yüzeyel (erken evre) ve ilerlemiş tümörler olmak üzere ikiye ayrılır (Şek. 1) (Japan Esophageal Society, 2009).

İnvazyonu mukoza ve submukozada sınırlı olan tümörler yüzeyel tip (0 tip), invazyonu muskularis propriaya ulaşmış veya aşmış olanlar ise ilerlemiş tip tümörler (Tip 1-5) olarak tanımlanır. Yüzeyel tip tümörler tip 0-I (yüzeyel ve lümene doğru gelişen tip) (=polipoid veya plak benzeri), tip 0-II (yüzeyel ve düz) ve tip 0-III (yüzeyel ve çökük) tümörler şeklinde sınıflandırılır. Tip 0-II tümörler ise hafif yükseklik gösteren (subtip 0-IIa), tümüyle düz (subtip 0-IIb) veya hafif çökük (subtip 0-IIc) tümörler şeklinde alt gruplara ayrılır. Tip 0-II tümörler genellikle gizli lezyonlar şeklindedir ve bunların saptanmasında lugol iodin solüsyonu veya toluidin mavisi eşliğinde yapılan kromoendoskopi yöntemi yardımcı olabilir (Bogomoletz ve ark., 1989). Endoskopik mukozal rezeksiyon (EMR) veya endoskopik submukozal diseksiyon gibi koruyucu cerrahi seçeneği olması nedeniyle tip 0-I ve 0-II lezyonların saptanabilmesi oldukça önemlidir (Kuwano ve ark., 2008).

"Japon Özofagus Kanser Topluluğu"nun sinıflamasına göre ilerlemiş tümörler, tip 1 (lümene doğru gelişen), tip 2 (ülseratif lokalize), tip 3 (ülseratif infiltratif), tip 4 (diffüz infiltratif), tip 5 (sınıflandırılamayan) şeklinde gruplandırılır (Şek. 2).

En az sıklıkta görülen tip 4 tümörler yaygın duvar içi yayılımla özofagus duvarında diffüz kalınlaşmaya, sertleşmeye neden olan, mukozada küçük bir hasar veya ülser oluşturan tümörlerdir. Tip 5 tümörler ise bu makrosksopik paternleri birarada içeren, belli bir gruba alınamayan lezyonlardir.

\section{Mikroskopi}

Mikroskopik olarak hücreler arası köprüleşmeler ve / veya tek hücre keratinizasyonu, keratin incileri şeklinde konsantrik keratinizasyon gösteren, yassı hücre farklılaşması bulunduran malign epitelyal tümörlerdir. Yassı epitel farklılaşma derecesine (normal non-neoplastik olgun yassı epitele benzerliğine), nükleer atipi ve mitoz yoğunluğuna göre; iyi, orta, az diferansiye ve andiferansiye tümörler şeklinde histolojik dereceleme yapılır. Tümörlerin büyük kısmı iyi- orta diferansiye tümörler grubunda yer alır. İyi diferansiye tümörlerde yaygın hücreler arası köprüleşmeler, keratin incileri izlenirken, diferansiasyon azaldıkça hücrelerde pleomorfizm ve atipi bulguları şiddetlenir ve keratinizasyon kaybı, hücreler arası köprüleşmelerde azalma görülür. Az diferansiye tümörlerde yassı hücre farklılaşması çok küçük bir odak şeklinde izlenir (Şek. 3).

Andiferansiye karsinomada ise yassı hücre farklılaşması gösteren mikroskopik özellikler izlenmez; ayırıcı tanı zorluğu yaşanan bu grupta immunohistokimyasal inceleme yardımcı olabilir.

YHK varyantları:

1. Verrüköz karsinoma

2. İğsi hücreli karsinoma

3. Bazaloid YHK 


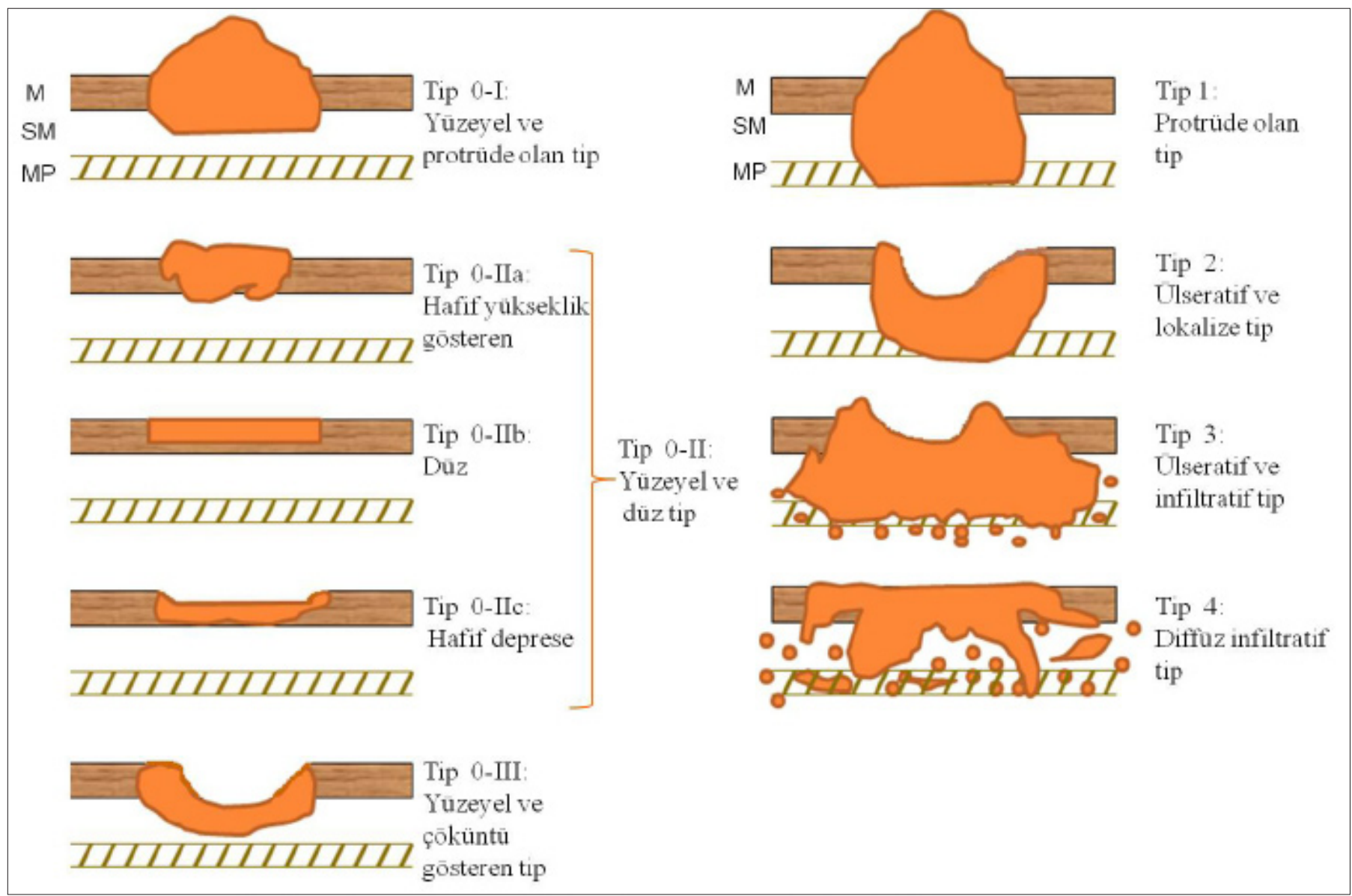

Şek. 1. Yassı hücreli karsinomanın makroskopik klasifikasyonu (Japan Esophageal Society, 2009). M:Mukoza, SM:Submukoza, MP: Muskularis propria.

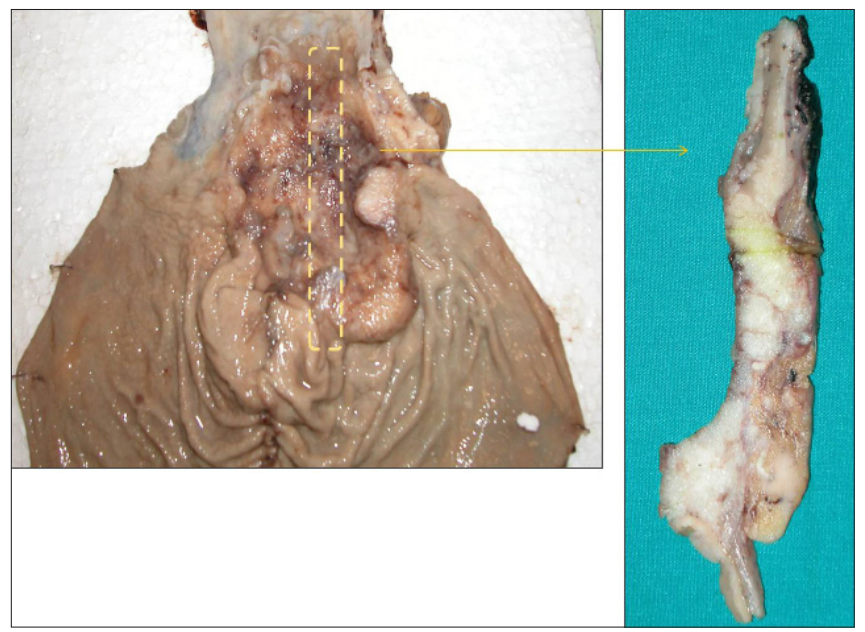

Şek. 2. Yassı hücreli karsinomanın tip 3 (ülseratif ve infiltratif tip) şeklinde makroskopik görünümü

\section{Verrüköz karsinoma}

YHK'nın iyi diferansiye olan seyrek bir varyantıdır. Yavaş büyür, lokal invazyon gösterebilir ve metastaz potansiyeli çok düşüktür. Makroskopik incelemede karnabahar benzeri (eksofitik, verrüköz veya papiller) bir görünüm içerir. Histolojik olarak minimal sitolojik atipi gösteren, iyi diferansiye, keratinize yassı epitelle karakterli, itici sınırları olan tümörlerdir (Osborn ve ark., 2003).

\section{İğsi hücreli karsinoma}

"Karsinosarkoma", "Psödosarkomatöz YHK", "Poli-

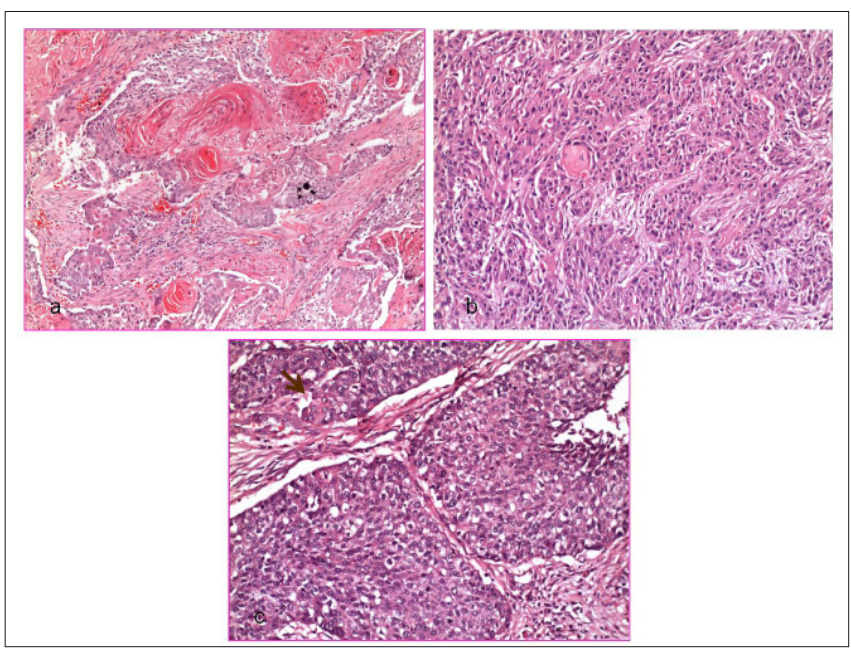

Şek. 3. a. Yaygın keratinizasyon ve keratin incilerinin izlediği iyi diferansiye yassı hücreli karsinoma (HEx10)

b. Keratinizasyonun daha sınırlı küçük birkaç odakta seçilebildiği orta diferansiye YHK (HEx20)

c. Yüksek mitotik aktivite ve belirgin atipi gösteren, çok küçük bir odakta keratinizasyonun seçilebildiği (okla işaretli) solid adalarla karakterli az diferansiye YHK (HEx20)

poid karsinoma", "İğsi hücre görünümlü YHK” gibi çeşitli şekillerde isimlendirilir (Levin ve Appelman, 1996). Makroskopik olarak polipoid kitle oluştururlar. İnvaziv YHK veya karsinoma in-situ (CIS) şeklinde izlenen epitelyal hücrelere, değişken oranda sarkomatoid iğsi hücrelerin eşlik ettiği, bu iki komponent arasında geçişlerin izlendiği seyrek bir YHK 
varyantıdır. İğsi hücreli alanlarda kemik, kıkırdak yapımı, çizgili kas gibi mezanşimal yönde farklılaşma görülebilir (Hanada ve ark., 1984). İğsi hücreli karsinomalar çok agresif gidişli tümörlerdir ve 5 yıllık sağkalım \% 10-15 oranındadır (Lauwers ve ark., 1998).

\section{Bazaloid YHK}

Tanı sırasında genellikle ileri evrede olan bu tümörler, lenf dügüumü metastazı ve hematojen metastazlar gösteren büyük kitleler oluştururlar (Cabrera ve ark., 1996).

Histolojik olarak sıkıca biraraya gelmiş, hiperkromatik çekirdekli, dar bazofilik sitoplazmalı hücrelerin oluşturduğu solid adalar, adalar çevresindeki hücrelerde palizatik dizelenim, küçük bez benzeri boşluklar ve ortası nekrozla karakterlidir (komedo tip) (Şek. 4). Yüksek mitotik aktivite görülür (15-40/10BBA). Komşuluğunda sıklıkla yassı hücre displazisi, CIS veya klasik YHK alanları bulunur (Guarino ve Micoli, 1992).

\section{Genetik özellikler}

Özefageal YHK'de hücre siklusu G1-S geçişinde düzenleyici olarak rol oynayan genlerle ilgili değişiklikler sık olarak görülür. Erken bir moleküler değişiklik olarak TP53 gen mutasyonu (17p13) intraepitelyal neoplazi (IEN) evresinde de sıklıkla saptanabilir. Karsinogenez sürecinde

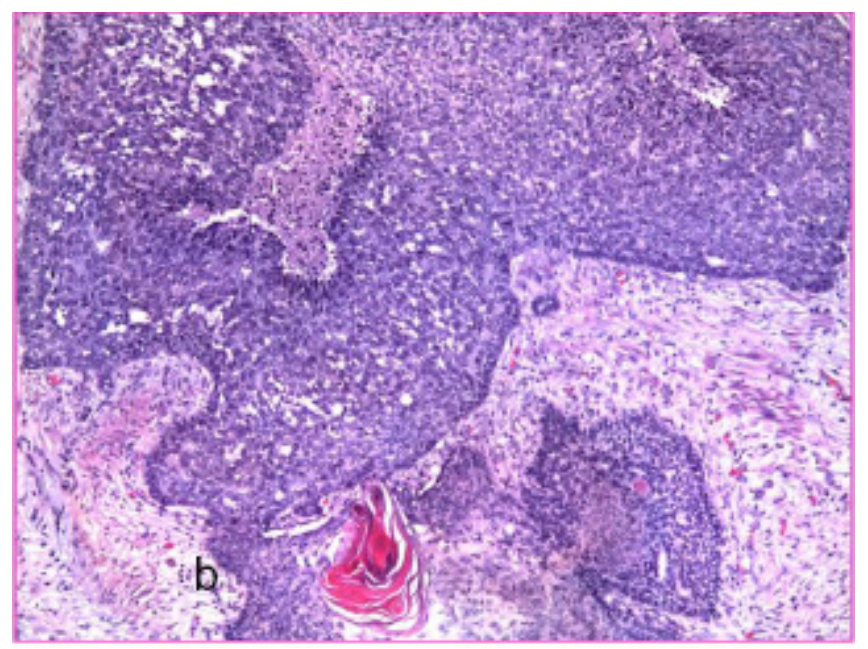

Şek. 4. Bazaloid tip yassı hücreli karsinoma. Hiperkromatik nükleuslu, dar bazofilik sitoplazmalı hücrelerin oluşturduğu solid adalar ve adalar çevresindeki hücrelerde palizatik dizelenim izleniyor (HEx10)

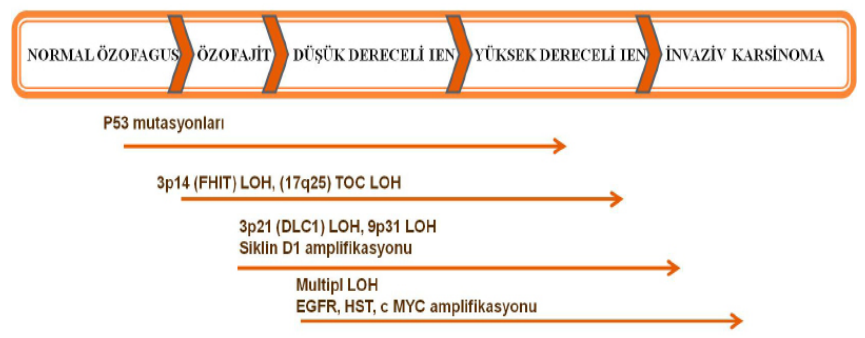

Şek. 5. Özofageal yassı hücreli karsinoma gelişiminde rol oynayan moleküller değişiklikler (FHIT: Fraji histidin triad, LOH: Loss of heterozygosity): Heterozigosite kayb1. TOC geniTylosis esophageal cancer, DLCI: Deleted in lung and esophageal cancer 1,EGFR: Epidermal growth factor receptor, HST: human stomach cancer transforming factor) gözlenen moleküler değişiklik basamakları Şekil 5'de verilmiştir (Montesano ve ark., 1996; Montesano ve Hainaut, 1998; Von-Brevern ve ark., 1998) (Şek. 5).

\section{Tümör yayılımı}

YHK'nın özofagus duvarında yayılımı horizontal veya vertikal olabilir. Tümör mukoza veya submukozada sınırlı ise, bölgesel lenf düğümü tutulumu dikkate alınmaksızın, yüzeyel (erken) özofagus kanseri, submukozayı aşan tümörler ise ilerlemiş özofagus kanseri olarak kabul edilir (Bogomoletz ve ark., 1989; Takubo ve ark., 2007). İnvazyonun submukozada sınırlı olduğu tümörlerde 5 yıllık sağkalım oranı \% 70 iken, muskularis propria invazyonu gösterenlerde bu oran $\%$ 40-50, adventisya invazyonu olanlarda ise \% 25-30'lara düşer (Sarbia ve ark., 1995; Tajima ve ark., 2000). Yüzeyel kanserlerde lenf düğümü tutulumu bulunmayan grupta EMR tedavi seçeneği olabilir.

Özofageal YHK'lar bazen yüzeyel yay1lım göstererek, sıklıkla da epitel içinde sınırlı kalarak, geniş çaplara ulaşabilmektedir. Mukozada sadece hafif bir çöküklük veya yükselme oluşturan bu tümörlerin makroskopik olarak farkedilmesi zordur. Bunların saptanabilmesi güvenli cerrahi sınırlara ulaşabilmek açısından önemlidir (Yuasa ve ark., 2001).

Özofageal YHK'larda duvar içi lenfovasküler yayılım sık (\% 16) görülür ve ileri evre, kısalmış sağkalım ile ilişkilidir (Kato ve ark., 1992). Bu tümörlerin en s1k metastaz yeri bölgesel lenf düğümleridir. Hastaların \% 60'1nda tanı sırasında bölgesel lenf düğümü metastazı görülür ve sıklığ tümörün invazyon derinliği ile paralellik gösterir. En s1k akciğer, karaciğer gibi organlara hematojen metastaz izlenir (Mandard ve ark., 1981; Sons ve Borchard, 1984).

\section{Prognostik faktörler}

Özofageal YHK'lar 5 yıllık sağkalımı \% 10 ile sınırlı olan kötü prognozlu tümörlerdir. Sadece yüzeyel kanserlerde kürden bahsedilebilmektedir. En önemli prognostik faktör tümör evresidir (Tablo 3) (Edge ve ark., 2009).

Gastroözofageal bileşke (GEB)'yi tutan YHK'lar, GEB'yi geçerek distale doğru yayılsa da distal özofagus kökenli kanserler olarak kabul edilir ve bu şekilde evreleme yapılır. Histolojik derecelemenin prognoza etkisi tartışmalı bir konu olmakla birlikte, 2009 “American Joint Committee on Cancer (AJCC)"ın önerdiği prognostik gruplamada tümör evresi yanısıra, tümör histolojik derecesi de kriterler arasına alınmıştır (Tablo 4). Ayrıca üst-orta lokalizasyondaki tümörlerin daha agresif seyretmesi nedeniyle bu prognostik gruplamada tümör yerleşim yeri de dikkate alınmaktadır (Edge ve ark., 2009).

\section{Öncü lezyonlar}

YHK gelişimi; normal yassı epitelden, İEN (displazi)'ye ve sonrasında invaziv YHK'ya ilerlemenin izlendiği çok aşamalı bir süreçtir (Qiu ve Yang, 1988; Dawsey ve ark., 1994).

\section{İntraepitelyal neoplazi (IEN) (Displazi)}

İEN, YHK için yüksek kanser riski olan bölgelerde düşük risk bölgelere göre sekiz kat daha fazla oranda görülür ve olguların \% 60-80'inde YHK'ya komşu alanlarda saptanır (Wei ve ark., 2005). Genellikle özofagus orta ve alt kısmını 


\begin{tabular}{|c|c|c|c|c|c|}
\hline \multicolumn{2}{|l|}{ T-Primer tümör } & \multicolumn{4}{|c|}{ Evre gruplaması } \\
\hline $\mathrm{Tx}$ & Primer tümör değerlendirilemiyor & & & & \\
\hline T0 & Primer tümör için kanıt yok & Evre & $\mathbf{T}$ & $\mathbf{N}$ & M \\
\hline Tis & Karsinoma in-situ/Yüksek dereceli displazi & 0 & Tis & No & M0 \\
\hline $\mathrm{T} 1$ & Tümör lamina propria, muskularis mukoza veya submukozayı infiltre ediyor & IA & $\mathrm{T} 1$ & No & M0 \\
\hline T1a & Tümör lamina propria veya muskularis mukozayı infiltre ediyor & IB & $\mathrm{T} 2$ & No & M0 \\
\hline $\mathrm{T} 1 \mathrm{~b}$ & Tümör submukozayı infiltre ediyor & IIA & $\mathrm{T} 3$ & No & M0 \\
\hline $\mathrm{T} 2$ & Tümör muskularis propriayı infiltre ediyor & IIB & $\mathrm{T} 1, \mathrm{~T} 2$ & N1 & M0 \\
\hline $\mathrm{T} 3$ & Tümör adventisyayı infiltre ediyor & IIIA & T4a & No & M0 \\
\hline $\mathrm{T} 4$ & Tümör komşu yapıları infiltre ediyor & & $\mathrm{T} 3$ & $\mathrm{~N} 1$ & M0 \\
\hline $\mathrm{T} 4 \mathrm{a}$ & Tümör plevra, perikard veya diafragmayı infiltre ediyor & & $\mathrm{T} 1, \mathrm{~T} 2$ & N2 & M0 \\
\hline $\mathrm{T} 4 \mathrm{~b}$ & Tümör vertebra, aorta veya trakea gibi komşu yapıları infiltre ediyor & & & & \\
\hline \multicolumn{6}{|c|}{ N-Bölgessel lenf nodülleri } \\
\hline $\mathrm{Nx}$ & Değerlendirilemiyor & IIIB & $\mathrm{T} 3$ & N2 & M0 \\
\hline N0 & Lenf nodu metastazı yok & IIIC & $\mathrm{T} 4 \mathrm{a}$ & $\mathrm{N} 1, \mathrm{~N} 2$ & M0 \\
\hline N1 & 1-2 bölgesel lenf nodu metastazı & & $\mathrm{T} 4 \mathrm{~b}$ & Herhangi bir $\mathrm{N}$ & M0 \\
\hline N3 & 7 veya daha fazla bölgesel lenf nodu metastazı & IV & Herhangi bir $\mathrm{T}$ & Herhangi bir N & M1 \\
\hline \multicolumn{6}{|l|}{ M-Uzak metastaz } \\
\hline $\mathrm{Mx}$ & Değerlendirilemiyor & & & & \\
\hline M0 & Uzak metastaz yok & & & & \\
\hline M1 & Uzak metastaz var & & & & \\
\hline
\end{tabular}

tutar ve sınırlı küçük bir lezyon şeklinde olabileceği gibi, sınırları belirsiz yaygın bir lezyon veya çok odaklı lezyonlar şeklinde görülebilir. Bazen de makroskopik olarak çok hafif bir mukozal çöküntü dışında bulgu oluşturmaz ve mukoza Lugol solusyonu ile boyanarak, boya almayan displastik odaklar tesbit edilebilir (Connor ve Sharma, 2004).

Histolojik incelemede epitelde organizasyon ve polarite kaybı gibi yapısal bozuklukların yanısıra, hücrelerde düzensiz, hiperkromatik nukleus, nukleus/sitoplazma oranında artış, pleomorfizm, kromatin kabalaşması ve artmış mitotik aktivite gibi "hücresel atipi” bulguları görülür.

İEN (displazi), düşük ve yüksek dereceli İEN şeklinde sınıflandırılmaktadır. Düşük dereceli İEN'de invaziv kansere ilerleme riski yüksek dereceli İEN'ye göre daha düşüktür (Shimizu ve ark., 2009). Düşük dereceli İEN'de yukarıda tanımlanan hücresel ve yapısal değişiklikler epitel kalınlığının alt $1 / 2$ 'sinde sinırlı kalırken, yüksek dereceli İEN'de bu değişiklikler epitelin üst $1 \frac{1}{2}$ 'sinde de görülür (Şek. 6).

$\mathrm{Bu}$ değişikliklerin tüm epitel kalınlığı boyunca izlendiği durumda yüksek dereceli İEN yerine "yassı hücreli CIS" şeklinde de isimlendirilebilir (Shimizu ve ark., 2009).

\section{Bazal hücre hiperplazisi}

Histolojik olarak yassı epitelde bazal hücre tabakası kalınlığının tüm epitelyal kalınlığın \% 15'ini aşması ile karakterizedir (Muto ve ark., 2005). Özofajite ikincil olarak görülen reaktif değişikliktir. Özofagus kanseri gelişimi ile ilişkisi tartışmalıdır.

\section{Adenokarsinoma}

Özofagus adenokarsinomaları \% 90 oranında Barrett özofagus (BÖ) zemininde gelişen ve sıklıkla özofagus alt 1/3'ünde yerleşim gösteren, bez epiteli yönünde farklılaşma gösteren malign epitelyal tümörlerdir. Nadiren üst özofagus mukozasındaki heterotopik gastrik mukozadan, mukozal, submukozal bezlerden ve trakeobronşial kalıntılardan gelişebilir (Bergmann ve Charnas, 1958).

Özofageal adenokarsinoma gelişiminde en önemli risk faktörü gastroözofageal reflü hastalığıdır (GERH) ve bu-

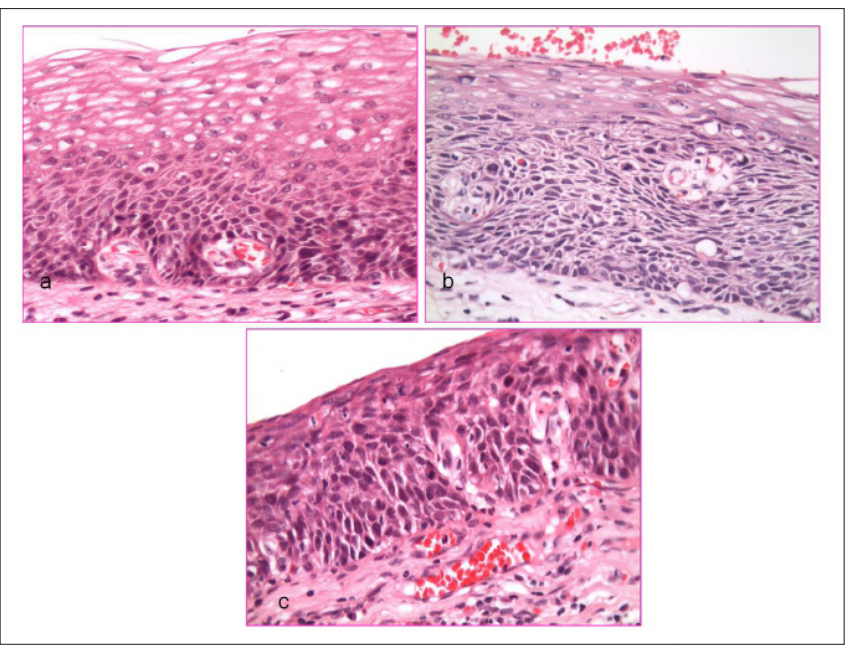

Şek. 6. a. Epitel kalınlığının yarısını geçmeyen polarite kaybı, nükleus/sitoplazına oranında artış, pleomorfizm ve mitozlarla karakterli düşük dereceli intraepitelyal neoplazi (IEN) (HEx40).b,c. Displastik değişikliklerin epitel üst 1/2'sine ulaştığı (b) veya tüm epitel kalınlığ 1 boyunca izlendiği (c) yüksek dereceli (İEN) (HEx40,x40)

nun zemininde gelişen BÖ'dur. GERH'ndan adenokarsinomaya ilerleme basamakları Şek. 7'de gösterilmiștir (Mueller ve ark., 2000; Chandrasoma ve DeMeester, 2006). BÖ gelişimi, GERH olan bireylerde \% 6-12 oranında görülür ve BÖ hastalarında adenokarsinoma gelişimi normal topluma göre 30-125 kat artmış olarak izlenir (Shaheen ve ark., 2000; Shaheen, 2005) (Şek. 7).

Endüstrileşmiş ülkelerde Bat1-tipi diyetle beslenmenin yol açtığı GERH sıklığındaki artışa paralel olarak özofagus adenokarsinomaları artan bir görülme sıklığı göstermektedir.

Distal yerleşimli özofagus kanserleri kardiaya veya kardia kanserleri sıklıkla özofagusa yayılabildiğinden, GEB' yi tutan adenokarsinomalar, "GEB adenokarsinomaları" adı altında ayrı bir grup olarak ele alınır. Bu grup, mide kökenli olup GEB'yi tutan pekçok tümörü de içine almaktadır.

GEB adenokarsinomalarının etiyolojisinde en önemli faktör GERH'dır. Mide kökenli olup GEB'yi tutanların etiyolojisinde ise Helicobacter pylori (Hp) enfeksiyonu ve 
Tablo 4. Prognostik gruplama (Edge ve ark., 2009)

\begin{tabular}{|c|c|c|c|c|c|c|c|c|c|c|}
\hline \multicolumn{6}{|c|}{ Skuamoz hücreli karsinoma } & \multicolumn{5}{|c|}{ Adenokarsinoma } \\
\hline Grup & $\mathbf{T}$ & $\mathbf{N}$ & M & Histolojik derece & Lokalizasyon & Grup & $\mathbf{T}$ & $\mathbf{N}$ & $\mathbf{M}$ & Histolojik derece \\
\hline 0 & Tis & 0 & 0 & 1 & Herhangi bir lokalizasyon & 0 & Tis & 0 & 0 & 1 \\
\hline IA & 1 & 0 & 0 & $1, \mathrm{X}$ & Herhangi bir lokalizasyon & IA & 1 & 0 & 0 & $1,2, \mathrm{X}$ \\
\hline \multirow[t]{2}{*}{ IB } & 1 & 0 & 0 & 2,3 & Herhangi bir lokalizasyon & IB & 1 & 0 & 0 & 3 \\
\hline & 2,3 & 0 & 0 & $1, \mathrm{X}$ & Alt, $\mathrm{X}$ & & 2 & 0 & 0 & $1,2, \mathrm{X}$ \\
\hline \multirow[t]{2}{*}{ IIA } & 2,3 & 0 & 0 & $1, \mathrm{X}$ & Üst, orta & IIA & 2 & 0 & 0 & 3 \\
\hline & 2,3 & 0 & 0 & 2,3 & Alt, X & IIB & 3 & 0 & 0 & Herhangi bir derece \\
\hline \multirow[t]{2}{*}{ IIB } & 2,3 & 0 & 0 & 2,3 & Üst, orta & & 1,2 & 1 & 0 & Herhangi bir derece \\
\hline & 1,2 & 1 & 0 & Herhangi bir derece & Herhangi bir lokalizasyon & IIIA & 1,2 & 2 & 0 & Herhangi bir derece \\
\hline \multirow[t]{3}{*}{ IIIA } & 1,2 & 2 & 0 & Herhangi bir derece & Herhangi bir lokalizasyon & & 3 & 1 & 0 & Herhangi bir derece \\
\hline & 3 & 1 & 0 & Herhangi bir derece & Herhangi bir lokalizasyon & & $4 a$ & 0 & 0 & Herhangi bir derece \\
\hline & $4 a$ & 0 & 0 & Herhangi bir derece & Herhangi bir lokalizasyon & IIIB & 3 & 2 & 0 & Herhangi bir derece \\
\hline IIIB & 3 & 2 & 0 & Herhangi bir derece & Herhangi bir lokalizasyon & IIIC & $4 a$ & 1,2 & 0 & Herhangi bir derece \\
\hline \multirow[t]{2}{*}{ IIIC } & $4 a$ & 1,2 & 0 & Herhangi bir derece & Herhangi bir lokalizasyon & & $4 b$ & $\begin{array}{l}\text { Herhangi } \\
\text { bir N }\end{array}$ & 0 & Herhangi bir derece \\
\hline & $\begin{array}{l}\text { Herhangi } \\
\text { bir T }\end{array}$ & 3 & 0 & Herhangi bir derece & Herhangi bir lokalizasyon & IV & $\begin{array}{l}\text { Herhangi } \\
\text { bir T }\end{array}$ & $\begin{array}{c}\text { Herhangi } \\
\text { bir N }\end{array}$ & 1 & Herhangi bir derece \\
\hline IV & $\begin{array}{l}\text { Herhangi } \\
\text { bir T }\end{array}$ & $\begin{array}{c}\text { Herhangi } \\
\text { bir N }\end{array}$ & 1 & Herhangi bir derece & Herhangi bir lokalizasyon & & & & & \\
\hline
\end{tabular}

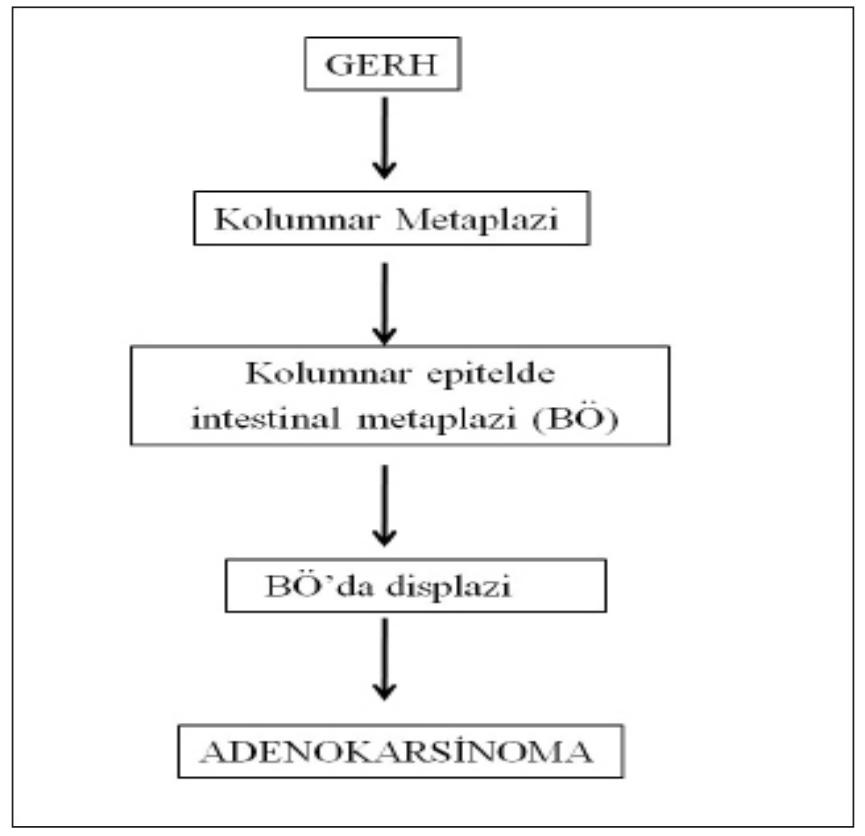

Şek. 7. Özofageal adenokarsinoma gelişim sıralaması.

daha az oranda otoimmun gastrit rol oynar (Parsonnet ve ark., 1991). Mide kökenli olanlar Hp veya otoimmun gastrit ilişkili intestinal metaplazi (IM)'li atrofik gastrit $\rightarrow$ Displazi $\rightarrow$ Adenokarsinoma şeklinde bir karsinogenik sıra gösterir (Şek. 8). Distal özofagusta izlenen İM'nin karsinomaya ilerlemesi, proksimal midede izlenen İM'ye göre daha yüksektir (Sharma ve ark., 2000).

\section{Makroskopi}

Erken evrede makroskopik olarak belirgin bir bulgu oluşturmayabilir veya düzensiz mukozal kabarıklık, küçük plak benzeri kalınlaşma şeklinde izlenebilir. Tanı sırasında tümörler genellikle özofagus duvarında derine infiltre olmuştur ve ülseratif ve daha az sıklıkta da polipoid lezyonlar oluşturur (Paraf ve ark., 1995; Van Sandick ve ark., 2000). Çok odaklı gelişim seyrek olarak izlenebilir (Levin ve Appelman, 1996).

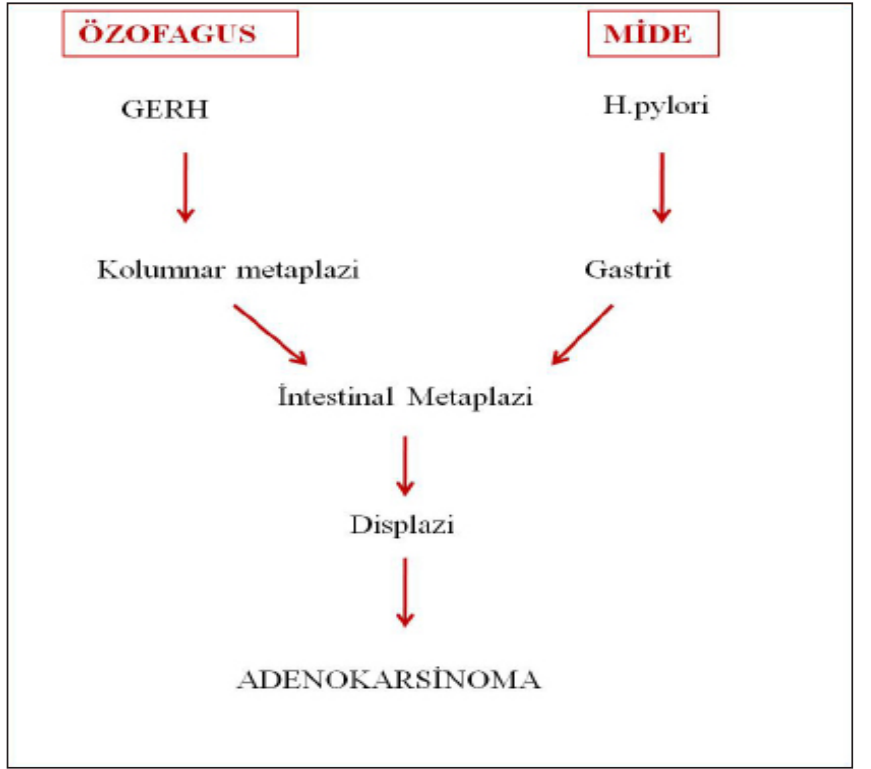

Şek. 8. Mide ve özofagus orjinli gastroözofageal bileşke adenokarsinomalarının karsinojenik sıralama

\section{Mikroskopi}

Özofagus adenokarsinomaları sıklıkla papiller ve/veya tübüler tipte izlenir. Bez epiteli yönünde farklılaşmanın çok seyrek olarak izlendiği, taşlı yüzük görüntüsünde hücrelerden oluşan diffüz infiltratif tip veya tümörün \% 50'den fazlasında müsin yapımı izlenen müsinöz adenokarsinomalar da görülebilir (Şek. 9) (Paraf ve ark., 1995).

\section{Histolojik dereceleme}

Bez yönünde farklılaşma derecesine göre yapılır. Tümörde bez yapılarının oranı $>\% 95$ ise iyi diferansiye, $\%$ 50-95 arasinda ise orta diferansiye ve \% 5-49 arasinda ise az diferansiye olarak derecelenir. Bazen aynı tümörde farklı diferansiasyon dereceleri birarada izlenebilir. Bu durumda en yüksek olan derece tümörün diferansiasyon derecesi olarak kabul edilmelidir. 


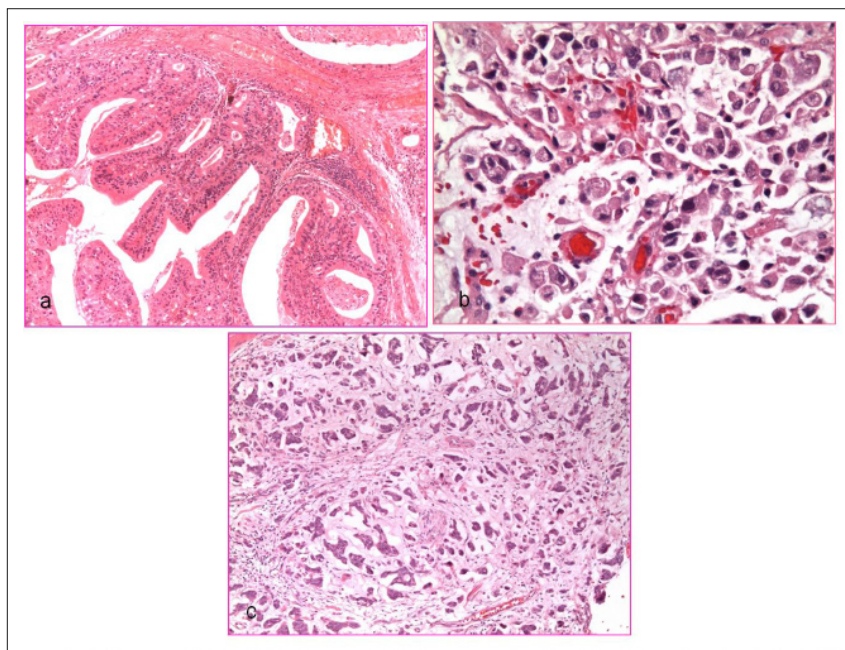

Şek. 9. a. Tübülopapiller organizasyon gösteren özofageal adenokarsinoma (HEx10) b. Taşlı yüzük hücreli karsinoma (Hex40). c. Müsin gölcükleri içerisinde gruplar, tübüler yapılar oluşturan tümör hücreleriyle karakterli müsinöz adenokarsinoma (HEx10)

\section{Tümör yayılımı ve evreleme}

Adenokarsinomalar ilk olarak özofagus duvarında lokal yayılım gösterir ve tanı sırasında büyük kısmı muskularis propria veya daha derine invaze olmuş ileri evre tümörler şeklinde izlenir. Mideye distal yayılım görülebilir. YHK'da olduğu gibi mukoza ve submukozada sınırlı tümörler "yüzeyel adenokarsinoma" olarak isimlendirilir.

Bölgesel lenf nodüllerine metastaz (periözofageal/perigastrik/çölyak) \% 50-60 oranında görülür (Paraf ve ark., 1995; Torres ve ark., 1999). Uzak metastazlar geç dönemde gelişir ve karaciğer, akciğer ve diğer gastrointestinal organlara izlenir. Bu tümörlerde özellikle submukozal lenfatikler boyunca yukarı yayılım çok sık olarak görülür, bu nedenle özofagus proksimal cerrahi sınırının intraoperatif frozen inceleme ile değerlendirilmesi önemlidir. Özofageal YHK için kullanılan TNM evreleme sistemi adenokarsinomalarda da kullanılır (Tablo 3). GEB adenokarsinomalarında tümörün merkezi GEB'den itibaren 5cm'lik aralık içindeyse ve tümör özofagusa uzanım gösteriyorsa özofagus kanseri gibi evreleme yapılır. Tümör merkezinin GEB'den uzaklığı $5 \mathrm{~cm}$ 'den fazla ise veya $5 \mathrm{~cm}$ 'lik uzaklık içerisinde kalıyor, ancak özofagusa uzanım göstermiyor ise mide kanseri gibi evreleme yapılır (Edge ve ark., 2009; Sobin ve ark., 2009). Ayrıca YHK'da olduğu gibi tümör yaygınlığının belirlendiği normal anatomik evreleme yanısıra, histolojik derecenin de kriter olarak alındığı prognostik evreleme yapılır (Tablo 4).

\section{Prognostik faktörler}

\section{Cerrahi sonrası prognostik faktörler}

En önemli prognostik faktör TNM patolojik evresidir. Mukoza ve submukozada sınırlı tümörlerde 5 yıllık sağkalım oran1 \% 80-100 iken, muskularis propria veya daha derine invazyon gösteren olgularda bu oran \% 10-20'ye düşer (Rice ve ark., 2001). Metastatik lenf düğümü sayısı ve lenf nodüllerinde kapsül dişına tümör invazyonu da prognozla ilişkili faktörlerdir (Korst ve ark., 1998; de Manzoni ve ark., 2004; Lagarde ve ark., 2006). Bu tümörlerde de YHK'ya benzer şekilde anatomik evreleme yanısıra tümör histolojik derecesinin de değerlendirmeye alındığı prognostik gruplama önerilmektedir (Edge ve ark., 2009).

\section{Preoperatif (radyo) kemoterapi ve cerrahi sonrası prognostik faktörler}

Preoperatif tedavi sonrası değerlendirilen histopatolojik tümör regresyon derecelemesi (TRG) önemli bir prognostik parametredir (Tablo 5) (Chang ve ark., 2008). Bu hastalarda tam tümör regresyonu (Berger ve ark., 2005), lenf düğümü tutulumu veya uzak metastazın olmaması en güçlü prognostik faktörler olarak saptanmıştır.

\begin{tabular}{|c|c|c|}
\hline P0 & $\% 0$ (rezidüel tümör yok) & Komplet tümör regresyonu \\
\hline P1 & $\% 1-50$ rezidüel tümör & Parsiyel tümör regresyonu \\
\hline $\mathrm{P} 2$ & $>\% 1-50$ rezidüel tümör & Minör regresyon/regresyon yok \\
\hline
\end{tabular}

\section{Barrett özofagus}

BÖ, distal özofagus ve GEB adenokarsinomalarının en önemli öncü lezyonudur. S1klıkla GERH'ye bağlı tekrarlayan mukozal hasarlar ve bunların iyileşme süreci sırasında normal yassı epitelin yerini kolumnar epitelin alarak bu zeminde İM gelişmesi ile karakterlidir (Spechler ve Goyal, 1996). Ancak bazı görüşlere göre İM'nin eşlik etmediği kolumnar metaplazi görülmesi de BÖ olarak kabul edilmektedir ve son dönemde yapılan çalışmalarda kolumnar metaplazide İM eşlik etmese de malignite potansiyelini arttırdığını göstermektedir. (Kelty ve ark., 2007). BÖ, genel populasyonda \% 1,6 oranında görülürken (Ronkainen ve ark., 2005). GERH bulguları nedeniyle endoskopi yapılan hastaların \% 10'unda izlenir. BÖ hastalarında adenokarsinoma gelişimi normal topluma göre 30-125 kat artmış olarak izlenir (Shaheen ve ark., 2000).

Endoskopik incelemede kolumnar döşenme uzunluğunun distal özofageal segmentte $3 \mathrm{~cm}$ veya daha fazla olması "Uzun segment BÖ", 3 cm'den az olması "K1sa segment BÖ", 1 cm'den az olması "Ultrakısa BÖ” olarak adlandırılır. Kısa segment BÖ olan hastalarda adenokarsinoma gelişim riski uzun segment BÖ olgularına göre daha düşüktür (Sharma ve ark., 1997).

BÖ genellikle bulgusuz seyreder. Bulgu veren olgulara genellikle GERH eşlik eder.

\section{Mikroskopi}

Özofagus mukozasında yüzeyde ve kriptlerde normalde beklenen yassı epitelin yerini İM gösteren müsinöz kolumnar epitelin aldığı görülür (Şek. 10).

BÖ’de İM genellikle kolumnar epitelde dağınık olarak izlenen goblet hücreleriyle karakterli inkomplet İM şeklindedir. Olgun absorptif barsak hücrelerinin bulunduğu firçamsı kenar görünümü içeren komplet İM seyrektir. Goblet hücreleri BÖ segmentinin proksimal kısımlarında daha yoğundur ve biyopsi örneklemesinde buna dikkat edilmesi önemlidir (Chandrasoma ve ark., 2001).

BÖ olgularında sıklıkla mukozada "muskularis mukoza duplikasyonu" izlenir (Şek. 11).

BÖ zemininde adenokarsinoma gelişimi olan olgularda tümör invazyon derinliği belirlenirken bu özellik mutlaka göz önünde bulundurulmalıdır. Yüzeydeki yeni oluşmuş muskularis mukoza iken, derindeki mukoza-submukoza sınırını oluşturan gerçek muskularis mukoza tabakasıdır. Tümör derindeki muskularis mukozayı aşmadığı sürece mukozada sınırlı kabul edilir (Offerhaus ve ark., 2003). 


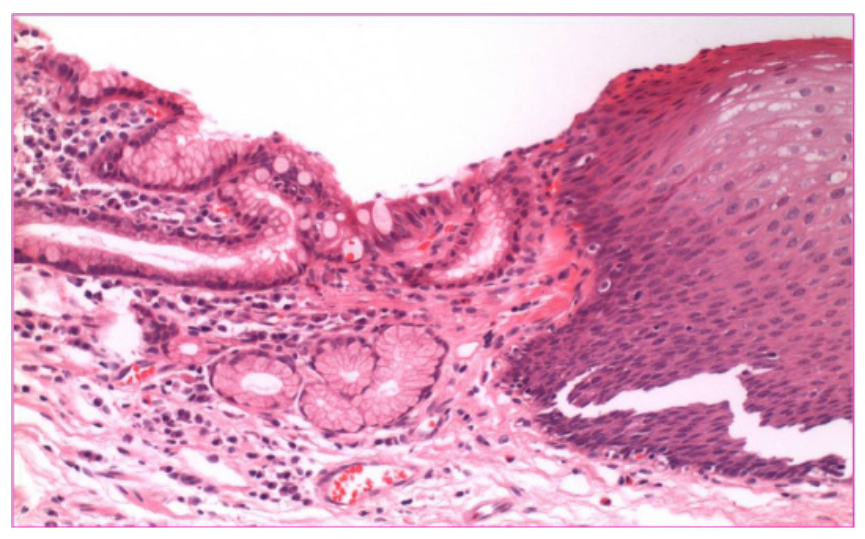

Şek. 10. Skuamoz epitel devamında intestinal metaplazi gösteren kolumlar epitel ile Barrett özofagus (HEx20)

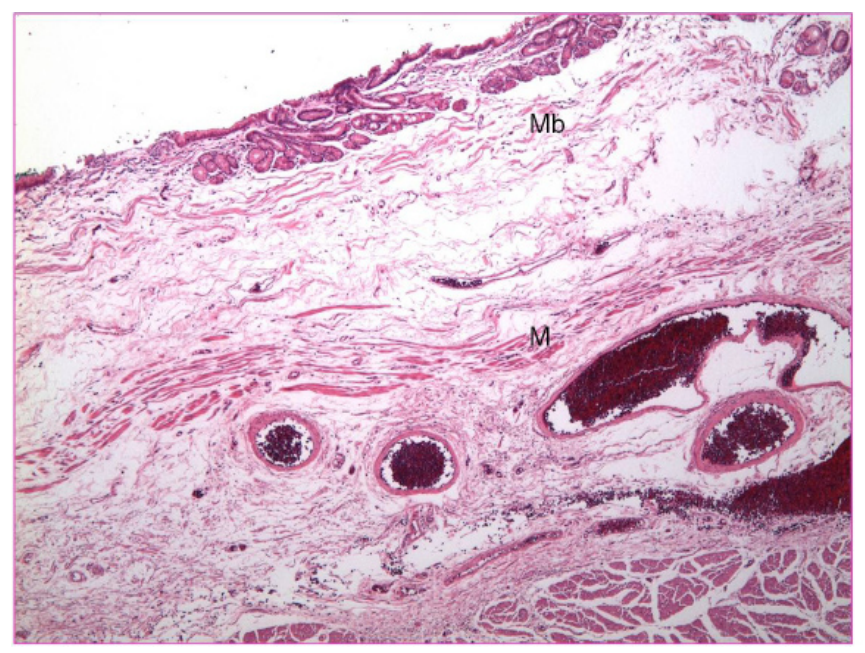

Şek. 11. Barrett özofagus (BO)'da izlenen muskularis mukoza duplikasyonu. Yüzeyde yeni oluşmuş muskularis mukoza $(\mathrm{Mb})$, derinde ise mukoza-submukoza sınırını oluşturan gerçek muskularismukoza (M) tabakası izleniyor (Hex4)

İnvazyonu iki muskularis mukoza tabakası arasında sınırlı olan tümörlerde, yüzeydeki muskularis mukozayı aşmamış tümörlere göre anjiolenfatik yayılım ve lenf düğümü metastazı daha s1k olarak izlenir (Abraham ve ark., 2007; Mandal ve ark., 2009).

GEB biyopsilerinde distal özofagus lokalizasyonlu ultra-kısa BÖ ile İM'li kardit ayrımının yapılması önemli bir problemdir. GEB, özofagusun mide ile birleştiğgi, mide mukozal kıvrımlarının başladığı çizgi olarak tanımlanır. Özofagus yassı epiteli ile mide kolumnar epitelinin birleşimi olan bölge ise skuamokolumnar bileşke ( $Z$ çizgisi) olarak adlandırılır. Genellikle Z çizgisi GEB ile üst üste gelir, ancak bazen normal bir değişiklik olarak mide fundus veya kardia mukozası küçük bir segment halinde $(\mathrm{mm}-1 \mathrm{~cm})$ distal özofagusa uzanım gösterebilir ve endoskopik olarak Z çizgisi GEB'in proksimalinde izlenir (De Hertogh ve ark., 2003). $\mathrm{Bu}$ nedenle GEB biyopsilerinde kardia mukozası uzantıs1 ile kolumnar metaplazi ayrımı, daha da önemlisi İM'nin eşlik ettiği durumda distal özofagus lokalizasyonlu ultrakısa BÖ ile İM'li kardit ayrımı çok zordur. İM'li kronik kardit sıklıkla etiyolojisinde Hp enfeksiyonun rol aldığı, malignite potansiyeli BÖ’a göre düşük olan ve antibiyotikle tedavi edilebilen bir durum iken (Goldblum, 2002; Odze, 2002). BÖ etiyolojisinde GERH yer alan, daha yüksek kanser riski bulunan, yakın takip gerektiren ve tedavisinde asit baskılanması veya cerrahi uygulanan bir patolojidir
(Odze, 2005). Bu iki antitenin ayırd edilebilmesi bu nedenle önemlidir. Bu olgularda $\mathrm{Z}$ çizgisinin üzerindeki yassı epitel mukozadan ve kardiadan da ek biyopsiler alınması, GERH veya Hp gastriti yönünde ipucu yakalanmaya çalışılması ayrımda yardımcı olabilir.

Patologlar morfolojik özelliklerin yardımıyla, GEB'den alınan biyopsi örneklerinin $\sim \%$ 30'unda, bu iki patolojinin ayrımını yapabilir (Srivastava ve ark., 2007). Büyük oranda morfolojik inceleme tek başına yeterli olmaz. Patolog ile endoskopiyi yapan klinisyen arasındaki iletişim bu noktada çok önemlidir.

\section{BÖ zemininde İEN}

BÖ’da malignite gelişimi; metaplaziden, düşük ve yüksek dereceli İEN ve invaziv karsinomaya geçişin izlendiği çok aşamalı bir olaydır. İEN negatif olan hastalarda invaziv karsinoma gelişimi çok seyrek olmakla birlikte, yüksek dereceli İEN varlığında hastaların \% 60 kadarında invaziv karsinoma gelişimi görülmektedir.

\section{Makroskopi}

IEN, makroskopik olarak mukozal hafif düzensizlik, noduler yapı, polipoid gelişim, erozyon, ülserasyon gibi farklı görünümler oluşturabileceği gibi, hiçbir makroskopik bulgu oluşturmayabilir. (Arnold ve Mardini, 2002; Hillman ve ark., 2003). Makroskopik olarak farkedilebilen lezyonu olan hastalarda yüksek dereceli displazi veya kanser gelişim riski daha yüksektir (Arnold ve Mardini, 2002; Montgomery ve ark., 2002; Hillman ve ark., 2003).

Özellikle makroskopik olarak adenomatöz polip benzeri görünüm oluşturan, "BÖ zemininde polipoid displazi" şeklinde tanımlanan olgularda komşu mukozada yüksek dereceli displazi ve adenokarsinoma birlikteliği sıktır (Thurberg ve ark., 1999; Arnold ve Mardini, 2002). Bunlar orta ve distal özofagusda, $0,5-1,5 \mathrm{~cm}$ çaplı, saplı veya sapsız polipler şeklinde izlenir. Yüksek dereceli displazi alanları sıklıkla çok odaklı ve gizli lezyonlar şeklinde izlendiğinden endoskopik incelemede bulgu saptanmayan olgularda da sistematik biyopsi örneklemesinin yapılması çok önemlidir (Falk ve ark., 1999).

\section{Mikroskopi}

Barrett mukozasında İEN'yi değerlendirirken, "İEN negatif", "İEN pozitif" ve "İEN için belirsiz atipi" şeklinde sınıflama yapılır. İEN varsa sitolojik ve yapısal özelliklerine göre düşük ve yüksek dereceli İEN şeklinde derecelenir (Odze, 2006).

\section{a. İEN negatif}

Siklıkla Barrett mukozasına hafif şiddette mononükleer hücresel infiltrasyon eşlik eder ve buna ikincil olarak epitel hücrelerinde nükleer büyüme, hiperkromazi, nukleol belirginliği ve hafif çok katlılaşma gibi reaktif değişiklikler görülebilir. İEN'den farklı olarak bunlar bezlerin bazal kısımlarında sınırlı kalır ve yüzeye ulaşmaz.

\section{b. İEN için belirsiz atipi}

İEN ile reaktif/rejeneratif epitelyal değişikliklerin ayrımını yapabilmek bazı durumlarda önemli bir problem oluşturur. Morfolojik özelliklerin yeterli olmadığ $\breve{1}_{1}$ durumlarda immunohistokimyasal olarak Ki-67 ve p53 incelemesi 
yapılabilir. Bu inceleme kesin ayrıma götürmemekle birlikte Ki-67 pozitifliğinin bezlerin bazalindeki çoğalma zonundan yüzeye doğru çıktığının görülmesi veya p53 pozitifliğinin seyrek birkaç hücre pozitifliğinin üstüne çıkması İEN lehine destekleyici olabilir (Lörinc ve ark., 2005; Hritz ve ark., 2009). Bu ayrımın net olarak yapılamadığ 1 durumlarda "IEN için belirsiz atipi" şeklinde rapor verilerek reflü tedavisinden sonra tekrar biyopsi önerilir.

\section{c. İEN pozitif (Düşük / Yüksek dereceli)}

Sitolojik ve yapısal atipi bulgularının şiddetine, kript epiteli üst yarısına, yüzeye ulaşması veya bazalde sınırlı kalmasına göre düşük ve yüksek dereceli şeklinde dereceleme yapılır (Şek. 12).

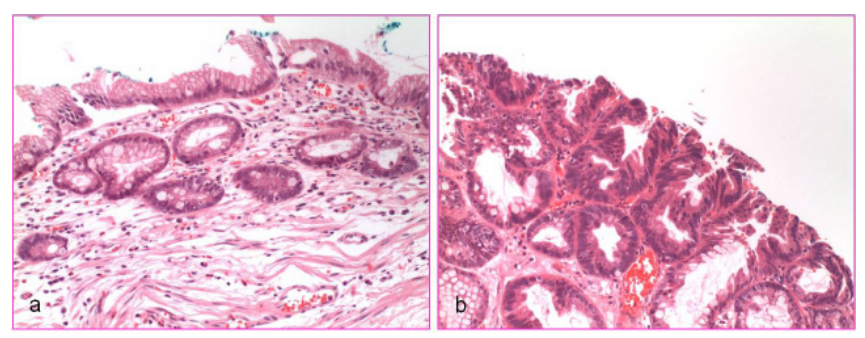

Şek. 12. Barret özofagus zemininde düşük dereceli (a) ve yüksek dereceli (b) intraepitelyal neoplazi (Hex20,x20).

İEN, Barrett mukozasında yaklaşık \% 10 oranında görülen, epitele sınırlı, bazal membranı aşmayan neoplazidir. Tümör hücrelerinin bazal membranı aşarak lamina propria veya muskularis mukozaya invazyonu "intramukozal kanserleşme" olarak tanımlanır. Anastomozlaşan bezler, bez epitelinde ikincil lümen yapımı, kribriform organizasyon ve tümör hücrelerinin lamina propriaya tek tek veya küçük gruplar halinde çıktığı görülür (Şek. 13).

Yüksek dereceli İEN olgularından invaziv karsinomaya ilerleme gösterecek olanların belirlenmesi çok zordur. Kitle lezyonu oluşturanlarda bu riskin arttığı belirtilmektedir (Rice ve ark., 1993).

BÖ zemininde kanser gelişiminde rol oynayan moleküler değişiklikler

P53 mutasyonları BÖ ilerlemesinde rol oynayan önemli moleküler değişikliktir. Genellikle p53 lokusunda heterozigosite kaybı (LOH) şeklinde izlenen bu mutasyonlar, displazi olmayan metaplastik mukozada ve düşük dereceli İEN gösteren BÖ olgularında da izlenir, ancak yüksek dereceli IEN ve adenokarsinoma gelişimi ile birlikte belirgin artış gösterdiği belirtilmektedir (Fléjou ve Svrcek, 2007). BÖ’ün kansere progresyonunda ayrıca p16 inaktivasyonu, adenomatöz polipozis koli (APC) hipermetilasyonu, büyüme faktörü reseptörlerinin (EGFR, ERBB2) amplifikasyonu gibi moleküler değişiklikler de önemli rol oynar (Wong ve ark., 2001; Wang ve ark., 2009; Ooi ve ark., 2010).

\section{Diğer malign epitelyal tümörler \\ Mukoepidermoid karsinoma}

Histolojik olarak solid adalar oluşturan yassı hücreler, bez yapıları oluşturan veya taşlı yüzük hücresi şeklinde izlenen mukus salgılayan hücreler ve bunlar arasında histolojik özellikler gösteren ‘intermediate` (geçiş) hücrelerle karakterlidir. Çok seyrek görülen bu tümörlerin özofageal submukozal bezlerden köken aldığı düşünülmektedir. Kötü prognozludur
(Sasajima ve ark., 1990).

\section{Adenoskuamoz karsinoma}

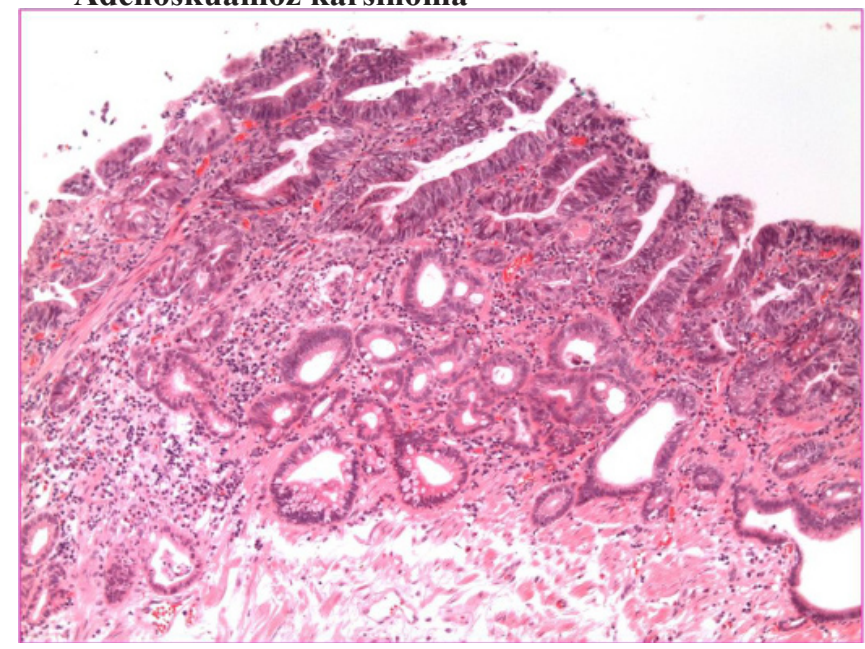

Şek. 13. Barret özofagus zemininde anastomozlaşan bez yapıları, kribriform yapıların izlendiği intramukozal kanserleşme (HEx10)

Seyrek görülen ve özellikle az diferansiye olduğunda çok agresif seyreden, mukozal yüzey boyunca pajetoid yayılım gösterebilen tümörlerdir. Mikroskopik incelemede YHK ve adenokarsinoma alanlarının birarada olduğu, geçişler gösterdiği izlenir. Bu tümörler mukoepidermoid karsinomaya göre daha agresif seyir gösterir, bu nedenle bu iki tümör grubunun ayırt edilmesi önemlidir (Ming, 1973).

\section{Adenoid kistik karsinoma}

Sıklıkla özofagus orta kısmında yerleşim gösteren bu tümörler makroskopik olarak polipoid kitle oluşturur ve mikroskopik incelemede epitelyal ve myoepitelyal hücrelerin oluşturduğu, lümeninde eozinofilik bazal membran materyali bulunduran tübüler ve kribriform yapılar ile karakterlidir. Sağkalımın kısa olduğu agresif tümörlerdir (Bell-Thomson ve ark., 1980).

\section{Nöroendokrin neoplaziler}

Özofageal nöroendokrin neoplaziler, WHO 2010 sinıflamasına göre Tablo 6'daki gibi sınıflandırılır (Bosman ve ark., 2010). Bunlar arasında nöroendokrin karsinoma (NEC) ve mikst adenonöroendokrin karsinoma (MANEC) en s1k görülen grubu oluşturur.

Özofageal nöroendokrin neoplaziler tüm gastrointestinal nöroendokrin neoplazilerin \% 0,05'ini oluşturur (Modlin ve Sandor, 1997) ve genellikle 6-7. dekad erkeklerde görülür. BÖ birlikteliği görülebilir (Saw ve ark., 1997; Saint Martin ve ark., 1999).

Nöroendokrin tümör (NET)'ler sıklıkla klinik bulgu vermez ve tesadüfen saptanır. NEC ve MANEC olguları ise tanı aldığında genellikle ileri evrededir ve disfaji, GERH, kilo kaybı, hematemez gibi bulgularla başvurur (Law ve ark., 1994).

Makroskopik olarak NET'ler küçük, polipoid, nadiren ülseratif lezyonlar şeklinde izlenir ve BÖ, adenokarsinoma birlikteliği sık olarak görülür. NEC ve MANEC ise çapı $4-10 \mathrm{~cm}$ arasında değişen, eksofitik veya ülseratif büyük kitleler oluşturur ve özofagus duvarında hızla derine infiltre olur (Klöppel ve ark., 2007). 


\begin{tabular}{|c|c|}
\hline \multicolumn{2}{|c|}{$\begin{array}{l}\text { Gastroenteropankreatik nöroendokrin } \\
\text { tümörlerin sinıflaması) } \\
\text { (Bosman ve ark., 2010) }\end{array}$} \\
\hline \multirow{2}{*}{\multicolumn{2}{|c|}{$\begin{array}{l}\text { WHO } 2010 \text { sınıflaması Histopatolojik kriterler } \\
\text { NE tümör }\end{array}$}} \\
\hline & \\
\hline NE tümör, Grade 1 (Karsinoid) & $\begin{array}{l}<2 \text { mitoz/10BBA ve }<\% 3 \mathrm{Ki} 67 \\
\text { indeks }\end{array}$ \\
\hline NE tümör, Grade 2 & $\begin{array}{l}2-20 \text { mitoz/10 BBA veya } \% 3-\% \\
20 \mathrm{Ki} 67 \text { indeks }\end{array}$ \\
\hline \multicolumn{2}{|l|}{ NE karsinoma } \\
\hline $\begin{array}{l}\text { Küçük hücreli NE karsinoma, } \\
\text { Grade } 3\end{array}$ & $\begin{array}{l}>20 \text { mitoz/10 BBA veya }>\% 20 \\
\text { Ki67 indeks }\end{array}$ \\
\hline \multicolumn{2}{|l|}{$\begin{array}{l}\text { Büyük hücreli NE karsinoma, } \\
\text { Grade } 3\end{array}$} \\
\hline Mikst adenöroendokrin karsinoma & $\begin{array}{l}\text { Eksokrin ve endokrin komponent } \\
\text { bir arada izlenir (Her bir } \\
\text { komponent tümörün \% } 30 \text { 'unu } \\
\text { geçmeli). }\end{array}$ \\
\hline
\end{tabular}

Özofagusta izlenen NEC'ların büyük kısmı büyük hücreli dir (Şek. 14).

MANEC'lar endokrin komponent olarak en s1k NEC, nadiren NET; ekzokrin komponent olarak ise adenokarsinoma veya nadiren YHK'nın izlendiği komposit tümörler şeklindedir. Histolojik dereceleme Tablo 5 'de belirtilen histopatolojik kriterlere göre yapılır. Nöroendokrin neoplazi tanısının verilebilmesi için immunohistokimyasal olarak başta Sinaptofizin, Kromogranin A olmak üzere CD56, CD57, Nöron spesifik enolaz gibi nöroendokrin belirleyicilerin pozitif olması gerekir.

Özofageal nöroendokrin neoplaziler çok az oranda

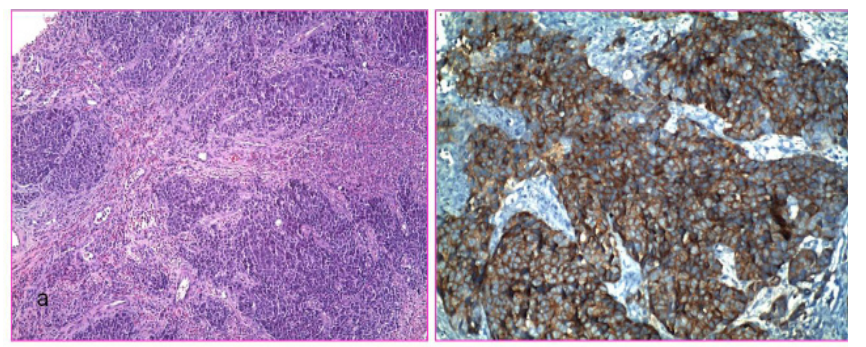

Şek. 14. Büyük hücreli nöroendokrin karsinoma. Solid adalar (a) şeklinde izlenen tümör hücrelerinde Sinaptofizin (b) ile yaygın sitoplazmik pozitiflik izleniyor (Hex10, Sinaptofizinx20)

görüldüğünden bu tümörler için oluşturulmuş ayrı bir evreleme sistemi yoktur. Özofagus karsinomaları için oluşturulmuş TNM evreleme sistemi bu tümörler için de önerilmektedir. Çok seyrek görülmeleri nedeniyle sağkalım bilgileri sınırlı olmakla birlikte, prognozun histolojik derece ve evre ile uyumluluk gösterdiği belirtilmektedir (Modlin ve ark., 2005).

İyi diferansiye NET'ler çok iyi prognoz gösterirken, az diferansiye NEC'larda ortalama 6 aydan az sağkalım izlenir (Law ve ark., 1994). Hızla derine infiltre olan NEC'de tanı sırasında metastazlar sık olarak görülür ve büyük ve küçük hücreli tip arasında sağkalım farkı bulunmamaktadır. MANEC'de ise prognozu ekzokrin komponent belirler ve tümör evresi ve histolojik diferansiasyon gibi özellikler önemlidir (Chong ve ark., 1979).

\section{KAYNAKLAR}

Abraham, S.C., Krasinskas, A.M., Correa, A.M., Hofstetter, W.L., Ajani, J.A., Swisher, S.G., Wu, T.T., 2007. Duplication of the muscularis mucosae in Barrett esophagus: An underrecognized feature and its implication for staging of adenocarcinoma. Am. J. Surg. Pathol. 31, 17191725.

Arnold, G.L., Mardini, H.E., 2002. Barrett's esophagus-associated polypoid dysplasia: A case report and review of the literature. Dig. Dis. Sci. 47, 1897-1900.

Bell-Thomson, J., Haggitt, R.C., Ellis, F.H. Jr., 1980. Mucoepidermoid and adenoid cystic carcinomas of the esophagus. J. Thorac. Cardiov. Sur. 79, 438-446.

Berger, A.C., Farma, J., Scott, W.J., Freedman, G., Weiner, L., Cheng, J.D., Wang, H., Goldberg, M., 2005. Complete response to neoadjuvant chemoradiotherapy in esophageal carcinoma is associated with significantly improved survival. J. Clin. Oncol. 23, 4330-4337.

Bergmann, M., Charnas, R.M., 1958. Tracheobronchial rests in the esophagus; their relation to some benign strictures and certain types of cancer of the esophagus. J. Thorac. Surg. 35, 97-104.

Blot, W.J., McLaughlin, J.K., Fraumeni, J.F., 2006. Esophageal cancer. Cancer Epidemiology and prevention. Oxford University Press, New York. pp. 697-706.

Bogomoletz, W.V., Molas, G., Gayet, B., Potet, F., 1989. Superficial squamous cell carcinoma of the esophagus. A report of 76 cases and review of the literature. Am. J. Surg. Pathol. 13, 535-546.

Bosman, F., Carneiro, F., Hruban, R., Theise, N., 2010, W.H.O. Classification of tumours of the digestive system. Fourth edition. IARC Press, Lyon, France.

Cabrera, E., Fernandes, F., Gomez- Roman, J., Val-Bernal, J.F., 1996. Basaloid squamous carcinoma of the esophagus: Immunohistochemistry and flow cytometric DNA analysis in two cases. Int. J. Surg. Pathol. 3, 267.

Chandrasoma, P., Der, R., Dalton, P., 2001. Distribution and significance of epithelial types in columnar-lined esophagus. Am. J. Surg. Pathol. $25,1188-1193$

Chandrasoma, P.T., DeMeester, T.R., 2006. GERD: Reflux to esophageal adenocarcinoma. Elsevier Academic Press, San Diego. $381-437$.

Chang, F., Deere, H., Mahadeva, U., George, S., 2008. Histopathologic examination and reporting of esophageal carcinomas following preoperative neoadjuvant therapy: Practical guidelines and current issues. Am. J. Clin. Pathol. 129, 252-262.

Chong, F.K., Graham, J.H., Madoff, I.M., 1979. Mucin-producing carcinoid (“composite tumor") of upper third of esophagus: A variant of carcinoid tumor. Cancer. 44, 1853-1859.

Connor, M.J., Sharma, P., 2004. Chromoendoscopy and magnification endoscopy for diagnosing esophageal cancer and dysplasia. Thorac. Surg. Clin. 14, 87-94.

Curado, M.P., Edwards, B., Shin, H.R., Storm, H., Ferlay, J., Heanue, M., 2007, Cancer incidence in five continents. I.A.R.C. Lyon, France.

Dawsey, S.M., Lewin, K.J., Wang, G.Q., Liu, F.S., Nieberg, R.K., Yu, Y., Li, J.Y., Blot, W.J., Li, B., Taylor, P.R., 1994. Squamous esophageal histology and subsequent risk of squamous cell carcinoma of the esophagus. A prospective follow-up study from Linxian, China. Cancer. $74,1686-1692$.

De Hertogh, G., Van Eyken, P, Ectors, N, Tack, J, Geboes, K., 2003. On the existence and location of cardiac mucosa: An autopsy study in embryos, fetuses and infants. Gut. 52, 791-796. 
de Manzoni, G., Pedrazzani, C., Verlato, G., Roviello, F., Pasini, F., Pugliese, R., Cordiano, C., 2004. Comparison of old and new TNM systems for nodal staging in adenocarcinoma of the gastro-oesophageal junction. Brit. J. Surg. 91, 296-303.

Edge, S.B., Byrd, D.R., Compton, C.C., Fritz, A.G., Greene, F.L., Trotti, A., 2009, A.J.C.C. Cancer staging manual. Springer, New York. pp. 103-115.

Enzinger, P.C., Mayer, R.J., 2003. Esophageal cancer. New Engl. J. Med. 349, 2241-2252.

Falk, G.W., Rice, T.W., Goldblum, J.R., Richter, J.E., 1999. Jumbo biopsy forceps protocol still misses unsuspected cancer in Barrett's esophagus with high-grade dysplasia. Gastrointest. Endosc. 49, 170-176.

Farhadi, M., Tahmasebi, Z., Merat, S., Kamangar, F., Nasrollahzadeh, D., Malekzadeh, R., 2005. Human papillomavirus in squamous cell carcinoma of esophagus in a high-risk population. World J. Gastroenterol. 11, 1200-1203.

Fléjou, J.F, Svrcek, M., 2007. Barrett's oesophagus--a pathologist's view. Histopathology. 50, 3-14.

Goldblum, J.R., 2002. The significance and etiology of intestinal metaplasia of the esophagogastric junction. Ann. Diagn. Pathol. 61, 67-73.

Guarino, M., Micoli, G., 1992. Basaloid-squamous carcinoma of the upper aerodigestive tract. Histopathology. 20, 462.

Hamilton, S.R., Aaltonen, L.A., 2000, World health organization classification of tumors, pathology and genetics of tumors of the digestive system. Third edition. IARCPress, Lyon. pp. 11- 19.

Hanada, M., Nakano, K., Li, Y., Yamashita, H., 1984. Carcinosarcoma of the esophagus with osseous and cartilagenous production. A combined study of keratin immunohistochemistry and electron microscopy. Acta. Pathol. Jpn. 34, 669-678.

Hillman, L.C., Chiragakis, L., Clarke, A.C., Kaushik, S.P., Kaye, G.L., 2003. Barrett's esophagus: Macroscopic markers and the prediction of dysplasia and adenocarcinoma. J. Gastroen. Hepatol. 18, 526-533.

Hritz, I., Gyorffy, H., Molnar, B., Lakatos, G., Sipos, F., Pregun, I., Juhasz, M., Pronai, L., Schaff, Z., Tulassay, Z., Herszenyi, L., 2009. Increased p53 expression in the malignant transformation of Barrett's esophagus is accompanied by an upward shift of the proliferative compartment. Pathol. Oncol. Res. 15, 183-192.

Japan Esophageal Society, 2009. Japanese classification of esophageal cancer, tenth edition: Part I. Esophagus. 6, 1-25.

Kanamoto, A., Yamaguchi, H., Nakanishi, Y., Tachimori, Y., Kato, H., Watanabe, H., 2000. Clinicopathological study of multiple superficial oesophageal carcinoma. Br. J. Surg. 87, 1712-1715.

Kato, H., Tachimori, Y., Watanabe, H., Itabashi, M., Hirota, T., Yamaguchi, H., Ishikawa, T., 1992. Intramural metastasis of thoracic esophageal carcinoma. Int. J. Cancer. 50, 49-52.

Kelty, C., Gough, M., Van Wyk, Q., 2007. Barrett's oesophagus: Intestinal metaplasia is not essential for cancer risk. Scan. J. Gastroenterol. 42, 1271-1274.

Klöppel, G., Rindi, G., Anlauf, M., Perren, A., Komminoth, P., 2007. Site-specific biology and pathology of gastroenteropancreatic neuroendocrine tumors. Virchows Arch. 451 Suppl. 1, 9-27.

Korst, R.J., Rusch, V.W., Venkatraman, E., Bains, M.S., Burt, M.E., Downey, R.J., Ginsberg, R.J., 1998. Proposed revision of the staging classification for esophageal cancer. J. Thorac. Cardiov. Sur. 115, 660-669.

Koruk, M., Onuk, M.D., Gürsan, N., Polat, G., Yılmaz, A., 2000. Özofagus kanseri: Klinik, endoskopik ve histopatolojik özellikleri. Endoskopi $11,1-5$.

Kuwano, H., Nishimura, Y., Ohtsu, A., Kato, H., Kitagawa, Y., Tamai, S., Toh, Y., Matsubara, H., 2008. Guidelines for diagnosis and treatment of carcinoma of the esophagus. April 2007 edition: Part I. Edited by the Japan Esophageal society. Esophagus. 5, 61-73.

Lagarde, S.M., ten Kate, F.J., de Boer, D.J., Busch, O.R., Obertop, H., van Lanschot, J.J., 2006. Extracapsular lymph node involvement in node positive patients with adenocarcinoma of the distal esophagus or gastroesophageal junction. Am. J. Surg. Pathol. 30, 171-176.

Lagergren, J., 2005. Adenocarcinoma of oesophagus: What exactly is the size of the problem and who is at risk? Gut. 1, 1-5.

Lauwers, G.Y., Grant, L.D., Scott, G.V., Carr, N.J., Sobin, L.H., 1998. Spindle cell squamous carcinoma of the esophagus: Analysis of ploidy and tumor proliferative activity in a series of 13 cases. Hum. Pathol. 29, 863-868.

Law, S.Y., Fok, M., Lam, K.Y., Loke, S.L., Ma, L.T., Wong, J., 1994. Small cell carcinoma of the esophagus. Cancer. 73, $2894-2899$.

Levin, K.J., Appelman, H.D., 1996. Tumors of the esophagus and stomach. AFIP Atlas of tumor pathology. AFIP, Washington, DC.

Lörinc, E., Jakobsson, B., Landberg, G., Veress, B., 2005. Ki67 and p53 immunohistochemistry reduces interobserver variation in assessment of Barrett's esophagus. Histopathology. 46, 642-648.

Mandal, R.V., Forcione, D.G., Brugge, W.R., Nishioka, N.S., Mino-Kenudson, M., Lauwers, G.Y., 2009. Effect of tumor characteristics and duplication of the muscularis mucosae on the endoscopic staging of superficial Barrett esophagus-related neoplasia. Am. J. Surg. Pathol. 33, 620-625.

Mandard, A.M., Chasle, J., Marnay, J., Villedieu, B., Bianco, C., Roussel, A., Elie, H., Vernhes, J.C., 1981. Autopsy findings in 111 cases of esophageal cancer. Cancer. 48, 329-335.

Ming, S.C., 1973. Tumors of the esophagus and stomach. An atlas of tumor pathology. 2nd series, Fasc. 7. AFIP, Washington, DC.

Modlin, I.M., Sandor, A., 1997. An analysis of 8305 cases of carcinoid tumors. Cancer. 79, 813-829.

Modlin, I.M., Shapiro, M.D., Kidd, M., 2005. An analysis of rare carcinoid tumors: Clarifying these clinical conundrums. World J. Surg. 29, 92-101.

Montesano, R., Hollstein, M., Hainaut, P., 1996. Genetic alterations in esophageal cancer and their relevance to etiology and pathogenesis: A review. Int. J. Cancer. 69, 225-235.

Montesano, R., Hainaut, P., 1998. Molecular precursor lesions in oesophageal cancer. Cancer Surv. 32, 53-68.

Montgomery, E., Bronner, M.P., Greenson, J.K., Haber, M.M., Hart, J., Lamps, L.W., Lauwers, G.Y., Lazenby, A.J., Lewin, D.N., Robert, M.E., Washington, K., Goldblum, J.R., 2002. Are ulcers a marker for invasive carcinoma in Barrett's esophagus? Data from a diagnostic variability study with clinical follow-up. Am. J. Gastroenterol. 97, 27-31.

Mueller, J., Werner, M., Siewert, J.R., 2000. Malignant progression in Barrett's esophagus: Pathology and molecular biology. Cancer Res. 155, 29-41.

Muto, M., Takahashi, M., Ohtsu, A., Ebihara, S., Yoshida, S., Esumi, H., 2005. Risk of multiple squamous cell carcinomas both in the esophagus and the head and neck region. Carcinogenesis. 26, 1008-1012.

Odze, R., 2002. Cytokerin 7/20 immunostaining: Barrett's oesophagus or gastric intestinal metaplasia? Lancet. 33, 1711-1713.

Odze, R.D., 2005. Unraveling the mystery of the gastroesophageal junction: A pathologist's perspective. Am. J. Gastroenterol. 100, $1853-1867$.

Odze, R.D., 2006. Diagnosis and grading of dysplasia in Barrett's oesophagus. J. Clin. Pathol. 59, 1029-1038.

Offerhaus, G.J.A., Correa, P., van Eeden, S., Geboes, K., Drillenburg, P., Vieth, M., vanVelthuysen, M.L., Watanabe, H., Sipponen, P., ten Kate, 
F.J., Bosman, F.T., Bosma, A., Ristimaki, A., van Dekken, H., Riddell, R., Tytgat, G.N., 2003. Report of an amsterdam working group on barrett esophagus. Virchows Arch. 443, 601-607.

Ooi, A., Zen, Y., Ninomiya, I., Tajiri, R., Suzuki, S., Kobayashi, H., Imoto, I., Dobashi, Y., 2010. Gene amplification of ERBB2 and EGFR in adenocarcinoma in situ and intramucosal adenocarcinoma of Barrett's esophagus. Pathol. Int. 60, 466-71.

Osborn, N.K., Keate, R.F., Trastek, V.F., Nguyen, C.C., 2003. Verrucous carcinoma of the esophagus: Clinicopathophysiologic features and treatment of a rare entity. Digest. Dis. Sci. 48, 465-474.

Paraf, F., Flejou, J.F., Pignon, J.P., Fékété, F., Potet, F., 1995. Surgical pathology of adenocarcinoma arising in Barrett's esophagus: Analysis of 67 cases. Am. J. Surg. Pathol. 19, 183-191.

Parkin, D.M., Bray, F., Ferlay, J., Pisani, P., 2005. Global cancer statistics, 2002. CA Cancer J. Clin. 55, 74-108.

Parsonnet, J., Friedman, G.D., Vandersteen, D.P., Chang, Y., Vogelman, J.H., Orentreich, N., Sibley, R.K., 1991. H. pylori infection and the risk of gastric carcinoma. N. Engl. J. Med. 325, 1127-1131.

Qiu, S.L., Yang, G.R., 1988. Precursor lesions of esophageal cancer in high-risk populations in Henan Province, China. Cancer. 62, 551-557.

Rice, T.W., Falk, G.W., Achkar, E., Petras, R.E., 1993. Surgical management of high-grade dysplasia in Barrett's esophagus. Am. J. Gastroenterol. 88, 1832-1836.

Rice, T.W., Blackstone, E.H., Goldblum, J.R., DeCamp, M.M., Murthy, S.C., Falk, G.W., Ormsby, A.H., Rybicki, L.A., Richter, J.E., Adelstein, D.J, 2001. Superficial adenocarcinoma of the esophagus. J. Thorac. Cardiov. Sur. 122, 1077-1090.

Ronkainen, J., Aro, P., Storskrubb, T., Johansson, S.E., Lind, T., Bolling-Sternevald, E., Vieth, M., Stolte, M., Talley, N.J., Agréus, L., 2005. Prevalence of Barrett's esophagus in the general population: An endoscopic study. Gastroenterology. 129, 1825-1831.

Saint Martin, M.C., Chejfec, G., 1999. Barrett esophagus-associated small cell carcinoma. Arch. Pathol. Lab. Med. 123, 112.

Sarbia, M., Bittinger, F., Porschen, R., Dutkowski, P., Willers, R., Gabbert, H.E., 1995. Prognostic value of histopathologic parameters of esophageal squamous cell carcinoma. Cancer. 76, 922-927.

Sasajima, K., Watanabe, M., Takubo, K., Takai, A., Yamashita, K, Onda, M., 1990. Mucoepidermoid carcinoma of the esophagus: Report of two cases and review of the literature. Endoscopy. 22, 140-143.

Saw, E.C., Yu, G.S., Wagner, G., Heng, Y., 1997. Synchronous primary neuroendocrine carcinoma and adenocarcinoma in Barrett's esophagus. J. Clin. Gastroenterol. 24, 116-119.

Shaheen, N.J., Crosby, M.A., Bozymski, E.M., Sandler, R.S., 2000. Is there publication bias in the reporting of cancer risk in Barrett's esophagus? Gastroenterology. 119, 333-338.

Shaheen, N.J., 2005. Advances in Barrett's esophagus and esophageal adenocarcinoma. Gastronterology. 128, 1554-1566.

Sharma, P., Morales, T.G., Bhattacharyya, A., Garewal, H.S., Sampliner, R.E., 1997. Dysplasia in short-segment Barrett's esophagus: A prospective 3-year follow-up. Am. J. Gastroenterol. 92, 2012-2016.

Sharma, P., Weston, A.P., Morales, T., Topalovski, M., Mayo, M.S., Sampliner, R.E., 2000. Relative risk of dysplasia for patients with intestinal metaplasia in the distal oesophagus and in the gastric cardia. Gut. 46, 9-13.

Shimizu, M., Nagata, K., Yamaguchi, H., Kita, H., 2009. Squamous intraepithelial neoplasia of the esophagus: Past, present, and future. J. Gastroenterol. 44, 103-112.

Sobin, L.H., Gospodarowicz, M.K., Wittekind, C., 2009, TNM classification of malignant tumors. Wiley- Blackwell, Oxford, UK.

Sons, H.U., Borchard, F., 1984. Esophageal cancer. Autopsy findings in 171 cases. Arch. Pathol. Lab. Med. 108, 983-988.

Spechler, S.J., Goyal, R.K., 1996. The columnar-lined esophagus, intestinal metaplasia,and Norman Barrett. Gastroenterology. 110, 614-621.

Srivastava, A., Odze, R.D., Lauwers, G.Y., Redston, M., Antonioli, D.A., Glickman, J.N., 2007. Morphological features are useful in distinguishing Barrett's esophagus from carditis with intestinal metaplasia. Am. J. Surg. Pathol. 31, 1733-1741.

Tajima, Y., Nakanishi, Y., Ochiai, A., Tachimori, Y., Kato, H., Watanabe, H., Yamaguchi, H., Yoshimura, K., Kusano, M., Shimoda, T., 2000. Histopathologic findings predicting lymph node metastasis and prognosis of patients with superficial esophageal carcinoma: Analysis of 240 surgically resected tumors. Cancer. 88, 1285-1293.

Takubo, K., Aida, J., Sawabe, M., Kurosumi, M., Arima, M., Fujishiro, M., Arai, T., 2007. Early squamous cell carcinoma of the oesophagus: The Japanese viewpoint. Histopathology. 51, 733-742.

Thurberg, B.L., Duray, P.H., Odze, R.D., 1999. Polypoid dysplasia in Barrett's esophagus: A clinicopathologic, immunohistochemical, and molecular study of five cases. Hum. Pathol. 30, 745-752.

Torres, C., Turner, J.R., Wang, H.H., Richards, W., Sugarbaker, D., Shahsafaei, A., Odze, R.D., 1999. Pathologic prognostic factors in Barrett's associated adenocarcinoma: A follow-up study of 96 patients. Cancer. 85, 520-528.

Van Sandick, J.W., van Lanschot, J.J., ten Kate, F.J., Offerhaus, G.J., Fockens, P., Tytgat, G.N., Obertop, H., 2000. Pathology of early invasive adenocarcinoma of the esophagus or esophagogastric junction: Implications for therapeutic decision making. Cancer. 88, $2429-2437$.

Von-Brevern, M., Hollstein, M.C., Risk, J.M., Garde, J., Bennett, W.P., Harris, C.C., Muehlbauer, K.R., Field, J.K., 1998. Loss of heterozygosity in sporadic oesophageal tumors in the tylosis oesophageal cancer (TOC) gene region of chromosome 17q. Oncogene. 17, $2101-2105$.

Wang, J.S., Guo, M., Montgomery, E.A., Thompson, R.E., Cosby, H., Hicks, L., Wang, S., Herman, J.G., Canto, M.I., 2009. DNA promoter hypermethylation of 16 and APC predicts neoplastic progression in Barrett's esophagus. Am. J. Gastroenterol. 104, $2153-2160$.

Wei, W.Q., Abnet, C.C., Lu, N., Roth, M.J., Wang, G.Q., Dye, B.A., Dong, Z.W., Taylor, P.R., Albert, P., Qiao, Y.L., Dawsey, S.M., 2005. Risk factors for oesophageal squamous dysplasia in adult inhabitants of a high risk region of China. Gut. 54, 759-763.

Wong, D.J., Paulson, T.G., Prevo, L.J., Galipeau, P.C., Longton, G., Blount, P.L., Reid, B.J., 2001. P16INK4a lesions are common, early abnormalities that undergo clonal expansion in Barrett's metaplastic epithelium. Cancer Res. 61, 8284-8289.

Yuasa, N., Miyachi, M., Yasui, A., Hayakawa, N., Hattori, T., Yoneyama, F., Hirabayashi, N., Nimura, Y., 2001. Clinicopathological features of superficial spreading and nonspreading squamous cell carcinoma of the esophagus. Am. J. Gastroenterol. 96, 315-321. 